\title{
1 Global offtake of wild animals from wetlands: critical issues for fish
}

\section{2 and birds}

3

4 Sarah Brotherton • Chris B. Joyce • Jörn P. W. Scharlemann

5

6 S. Brotherton • J. P. W. Scharlemann $(\bowtie)$

7 School of Life Sciences, University of Sussex, Brighton BN1 9QG, UK

$8 \quad$ e-mail: j.scharlemann@sussex.ac.uk

9

10 S. Brotherton • C. B. Joyce $(\square)$

11 Centre for Aquatic Environments, School of Environment and Technology, University of

12 Brighton, Brighton BN2 4GJ, UK

13

e-mail: c.b.joyce@brighton.ac.uk

14

\section{J. P. W. Scharlemann}

16 United Nations Environment World Conservation Monitoring Centre, 219 Huntingdon Road,

17 Cambridge CB3 0DL, UK

19 Abstract

20 The global offtake of wild animals is valued at US\$400 billion annually and supports the

21 livelihoods of $15 \%$ of the global population. Wetlands are amongst the most important ecosystems globally, but offtake may represent a substantial pressure. This study assessed the

23 availability of information and evaluated the offtake of wild animals from wetlands by focussing

24 on fish and waterbirds. A literature search identified 2726 studies on wetland offtake. Scoping of 25 these resulted in 82 studies that contained quantitative information on fish or waterbird offtake. 
26 Fishing offtake statistics for inland waters are collated nationally by some governments, but other

27 sources of information are few. Reporting of fish offtake for species or across scales was

28 constrained by insufficient detail, even in relatively well-documented countries such as

29 Bangladesh. Although government hunting statistics from Europe and North America were

30 available, there was little waterbird data from less economically developed countries. The case

31 of Canada indicated that the species richness and composition of waterbirds taken varied between

32 indigenous subsistence and recreational hunting communities. Hidden (unquantified) offtake, of

33 both fish and waterbirds, hinders obtaining precise data for offtake, which may threaten the

34 conservation of species and the sustainability of wetland ecosystems.

35

36 Keywords Harvesting $\bullet$ Hunting $\bullet$ Fishing $\bullet$ Sustainable $\bullet$ Bangladesh $\bullet$ Canada

37 
The global harvest of wild animals from land and sea has a commercial value of over US\$400 billion annually and supports the livelihoods of $15 \%$ of the global population (Milner-Gulland et al. 2003; Brashares et al. 2014). Throughout human history, wild animal and plant species have been taken and used for food, fur and skins, fuel, traditional medicine, rituals, pets, sport, objects of scientific interest and curios, and as food for farmed animals, such as wild fish used as feed in aquaculture. Even today, wild species are the main source of protein for more than a billion people (Brashares et al. 2014). Advances in harvesting technology (e.g. guns, sonar use in fishing, wireless communication, Global Positioning System) and refrigeration have increased the frequency and quantity of wild species harvests in recent decades (Tsuji and Nieboer 1999). Overexploitation, the harvesting of wild species at unsustainable rates, is considered the biggest driver of biodiversity declines for more than 8,000 threatened or near-threatened species assessed by the International Union for Conservation of Nature (IUCN) Red List (Maxwell et al. 2016). Exploitation of wild species can lead to extinctions, with ultimately negative impacts on ecosystem functioning and human wellbeing.

The taking, exploiting or harvesting of animals from the wild, referred to here as offtake, is beginning to be recognised by policymakers and reflected in international and national policies. While information is available for marine offtake (e.g., Pauly 2007), recent assessments of threats to species highlighted the need for better knowledge on the use of biological resources, especially from terrestrial and freshwater ecosystems (Pereira et al. 2012; Joppa et al. 2016). Information on wild animal offtake and use is critical for reporting towards multiple international conventions and targets, including the Convention on Biological Diversity (CBD) Aichi Targets (e.g. Strategic Goal B) (UNEP and CBD 2010), the UN Sustainable Development Goals (especially 
the Food and Agriculture Organisation of the United Nations (FAO) Food Security Indicators, and also to inform national wildlife and food security policies.

Wetlands are vitally important for wildlife, supporting a richness of global biodiversity disproportionate to their limited extent (WWF 2018). Wetlands are areas that are inundated or saturated by surface or groundwater at a frequency or duration sufficient to support vegetation adapted for saturated soils. They can be natural or artificial, permanent or temporary, with water that is static or flowing, fresh, brackish or salt up to $6 \mathrm{~m}$ deep (United Nations Educational Scientific and Cultural Organization (UNESCO) 1971). They encompass a range of inland and coastal ecosystems, including rivers and lakes, floodplains, swamps, marshes, peatlands, mangroves, and rice fields. Wetland ecosystems contribute to peoples wellbeing and support vital services, including nutrient cycling, carbon storage, water purification, flood attenuation, and recreation (Russi et al. 2013). Their valuable provisioning services include drinking water, building materials, forage, fuel and food, such as fish and rice, thereby contributing to water and food security.

The global value of the provisioning services for coastal and inland wetlands, including rivers and lakes, is likely to be equivalent to at least Int $\$ 3.33$ trillion $\mathrm{yr}^{-1}$, representing almost 5\% of global GDP (Costanza et al. 2014). This is based on a cautious average of Int $\$ 2,190 \mathrm{ha}^{-1} \mathrm{yr}^{-1}$ (2007 values) (de Groot et al. 2012) and a conservative estimate of the global extent of wetlands at $15.2 \times 10^{8}$ ha (Davidson and Finlayson 2018). The food service value alone is on average Int $\$ 610 \mathrm{ha}^{-1} \mathrm{yr}^{-1}$ (de Groot et al. 2012), equivalent to Int $\$ 927$ billion $\mathrm{yr}^{-1}$ for the estimated global wetland resource. Animals taken from wetlands constitute a major source of protein in many human diets globally (Youn et al. 2014), especially where animal husbandry is less prevalent, or wetlands are not suitable for grazing livestock. Subsistence fishing, where fish are caught and consumed by the fisher and family, provides an important source of high-quality protein and micronutrients in many low-income countries (Youn et al. 2014). Fishing in wetlands can also 
generate income for rural communities and represent a vital source of employment for many women (Cooke et al. 2016). The fishing services at the 320,000 ha Lake Chilwa wetlands in Malawi were valued at over US\$18 million in 2002 (Schuyt and Brander 2004). Sports fishing on wetlands has been valued at US\$374 $\mathrm{ha}^{-1} \mathrm{yr}^{-1}$ and recreational hunting of birds and game at US\$123 ha $\mathrm{yr}^{-1}$ (Schuyt and Brander 2004). Where hunting and fishing for sport or recreation requires the purchase of licences, this can generate substantial income, such as the $£ 21$ million (US\$27 million) spent on fishing licences in England in 2015-16 (Environment Agency 2019).

The biodiversity of wetlands is amongst the most threatened of any ecosystem, and human offtake may represent a significant pressure affecting wetland-dependent taxa. Recent indicators suggest an $83 \%$ decline in global populations of freshwater species since 1970 (WWF 2018). Fish and waterbirds are among the most important indicators of wetland health and functioning (Weller 1999; Batzer and Sharitz 2014). The Ramsar Convention on Wetlands (2018) reports that $29 \%$ of freshwater fish species and $18 \%$ of waterbirds are threatened. It is estimated that inland wetlands including rivers and lakes support about 15,000 species of fish (Lévêque et al. 2008), of which over half are threatened, endangered, or extinct in the wild (He et al. 2018). In the $20^{\text {th }}$ century, freshwater fish had the highest global extinction rate of any vertebrates (Burkhead 2012). Overexploitation now accounts for 55\% of all threats to fish populations (WWF 2018). Waterbirds depend on inland and coastal wetlands for breeding and/or food, and include some of the most conspicuous and iconic wetland wildlife, including ducks, geese, swans, wading birds, herons, cranes, and flamingos. Population trends for waterbirds

107 globally indicate that $38 \%$ of species are in decline, with Anatidae (ducks, geese and swans) and 108 Raillidae (rails, crakes, coots etc.) the most threatened (Wetlands International 2012). The IUCN lists 58 wetland bird species that are globally endangered by hunting, with a further 68 species 110 categorised as vulnerable (IUCN 2018). In China, 71\% of endangered waterbirds are threatened 111 by hunting and historical studies suggest up to $50 \%$ of overwintering birds were taken annually 
112 from some floodplains (Wang et al. 2018). Many waterbirds are also taken on migration along

113 flyways between winter feeding and summer breeding wetlands (Boere and Piersma 2012).

114 In addition to fish and birds, offtake for a variety of uses represents a substantial threat to

115 a wide range of wetland vertebrate and invertebrate taxa. The IUCN lists 53 mammal species of

116 wetland habitats as vulnerable or threatened by hunting and trapping (IUCN 2018). Examples of

117 wetland-dependant mammals taken include otters that are trapped and hunted for meat as well as

118 perceived pest control in Africa and Asia, and hippopotamuses, which are often illegally hunted

119 for meat and ivory, especially since bans on the trade in elephant ivory (Veron et al. 2008).

120 Amphibians are taken for food and the pet trade (Vences and Köhler 2008) with, for example,

121 the USA importing over 14.7 million 'wild-caught' amphibians between 1998 and 2002

122 (Schlaepfer et al. 2005). Freshwater reptiles are amongst the most threatened wetland taxa

123 (Ramsar Convention on Wetlands 2018) and turtles are the most exploited of the reptiles,

124 primarily for their meat, eggs, medicinal use and the pet trade. Consequently, 30 wetland turtle

125 species are listed as either vulnerable, endangered or critically endangered (IUCN 2018). A

126 diversity of invertebrate species, ranging from crustaceans to molluscs and insects, are taken from

127 wetlands, likely in very large numbers. Almost 50,000 tonnes of aquatic invertebrates, not

128 including crustaceans and molluscs, were caught globally in 2009, mostly in China (Welcomme

129 2011). Water beetles, for example, are consumed and used in traditional medicines particularly

130 in Asia (Jäch and Balke 2007). Historic examples of overexploitation include freshwater leeches,

131 mussels, and crayfish (Strayer 2006), and over 30\% of non-marine mollusc and crayfish species

132 are globally threatened (Ramsar Convention on Wetlands 2018).

133 The importance of wetland animals is not limited to their resource value for humans; they

134 also fulfil vital functions within wetland ecosystems that offtake may disrupt. These include:

135 dispersal of plant seeds by mammals and birds (Green et al. 2007); consumption of weed seeds

136 and invertebrate pests by birds in agricultural wetlands (Sandilyan and Duraimurugan 2013); 
137 herbivory by birds that maintains vegetation structure and diversity (Green and Elmberg 2014); nutrient cycling and aeration of sediments through bioturbation by crustaceans, amphipods and gastropods (Covich et al. 1999; Vaughn and Hakenkamp 2001); and ecological engineering by

140 beavers that creates new wetlands (Rossell et al. 2005).

Given the global importance of wetlands and their services, the decline in their biodiversity (Ramsar Convention on Wetlands 2018), and the pressures on endangered wildlife, it is vital that the offtake of wild animals from wetlands is evaluated. Unlike marine systems, for which offtake and its sustainability have long been of interest (e.g. Pauly 2007), there is limited research on animal offtake from wetlands with a global perspective. This paper assesses the availability of information and evaluates the offtake of wild animals from wetlands by focussing on two key taxa: fish and waterbirds. Its objectives are to:

i) Systematically search and critically review the global literature and data sources on waterbird and fish offtake from wetlands to ascertain their availability and scope, and ii) Analyse the data and other information reviewed to present cases that exemplify and elucidate key trends and patterns in offtake from wetlands.

\section{Methods}

154 Searches for information on wetland offtake, with a focus on fish and birds, were conducted between May and July 2018 by retrieving relevant literature using a series of target words combined across themes in search strings in Web of Science and Google Scholar (Table 1). Boolean operators AND and NOT were used to combine words and exclude other terms. A wildcard (*) was used to incorporate multiple word endings (e.g. fish* er, ing, ery, etc). The full range of years available was used in all searches, extending back to 1900 . When less than four

160 results were returned in a search of article or report titles only, the search was expanded to include

161 topic so that keywords would also be incorporated. Additional information, such as from non 
162 peer-reviewed reports, was obtained following recommendations from an expert advisory panel, which met in July 2018.

164 Screening for the most relevant information involved evaluating titles and abstracts of all 165 publications retrieved from the initial search results in relation to the following five criteria. All

166 relevant documents were identified and stored.

168 Subject: The scope of wetlands included was based upon the Ramsar classification of wetland 169 types (Ramsar Convention 2012), adapted by Davidson and Finlayson (2018). This comprises 170 three main types of wetland: inland natural, used to assess both fish and bird offtake, and coastal 171 natural and human-made, used for birds only to avoid likely cases of marine fisheries and 172 aquaculture. The extent of inland natural wetlands is dominated by peatlands, lakes, and marshes and swamps (including floodplains), which together form over $80 \%$ of the global area of surface inland wetlands, with a smaller area of rivers and streams (Davidson and Finlayson 2018). Natural coastal wetlands include saltmarshes and tidal flats, which together form over $60 \%$ of 176 the global coastal wetland area (Davidson and Finlayson 2018), as well as mangroves and seagrass beds. The main areas of human-made wetlands are rice fields and water storage bodies such as reservoirs and ponds.

Taxa: The focal taxa were fish and waterbirds that depend upon wetlands to complete their life

181 cycle. For fish, this included wholly freshwater and diadromous species, both those that migrate

182 from marine to freshwater to breed, such as the anadromous salmonids, and catadromous species 183 like eels that return from freshwater to the sea to reproduce. Waterbird species that use inland and coastal wetlands were included. Many waterbirds are mobile between inland wetlands such as floodplains, wet grasslands and mires, where they might breed, and coastal wetlands such as marshes or lagoons where they might stop on migration or overwinter (Weller 1999). Examples 
187 include ducks and wading birds. Some sea ducks may also use inland wetlands, for example

188 during winter, inclement weather, or to breed (Duda et al. 2018).

189

190 Geography: The search was applied globally. Data from multiple sources for the same

191 geographical area were commonly found (e.g. waterbird hunting statistics for European and

192 North American countries, and river basin data, often comprising several countries, for fish).

193

194 Date: No date restrictions were applied. Data covering multiple years were of particular interest 195 as they enabled assessment of temporal trends.

196

197 Language: The search was conducted, and most information was returned, in English. However, some government hunting statistics and data sets were translated into English to enable them to

199 be integrated into the assessment.

200

Finally, the literature was scrutinised to identify case study issues of interest, namely

202 reasons for offtake, geographical (e.g. country) or species-specific studies, examples of 203 (un)sustainable offtake, and statistical analysis. Most of the quantitative information on fish and

204 bird offtake reported in the literature was traced to two main data sources. The FAO maintain 205 national records of inland fisheries from 1950 onwards in the 'fishstat' database (FAO Fisheries 206 and Aquaculture Department 2016). For waterbirds, governments of many of the more 207 economically developed countries have open access data on hunting, some going back several 208 decades. The European Federation for Hunting and Conservation (https://www.face.eu/) 209 provides web links to national statistics for hunting in Europe. 


\section{Results of the literature search}

212 The initial literature searches resulted in 2726 articles or reports (subsequently called studies)

213 being identified. The most successful search strings with more than 200 studies each in Web of

214 Science were: 'floodplain* AND fish*'; 'fish* AND exploit* NOT marine NOT reef NOT 215 coast'; 'illegal AND bird' and 'inland AND fish*'.

216 Reviewing the studies highlighted a variety of terms being used to describe the taking of

217 animals by humans from the wild, including: use, exploit, overexploitation, take, offtake, hunt,

218 harvest, fish and capture. Some terms were used more frequently in relation to particular taxa,

219 such as 'capture' for fish and 'hunt' for birds, while others such as 'harvest' were used commonly

220 for both. However, nuanced differences in application or implied meaning for some terms were apparent between taxa. For example, the term 'exploit' often suggested negative connotations within studies on waterbirds, but for fish tended to imply their beneficial use as a resource, unless overexploitation was explicitly mentioned. To overcome ambiguity, here the term 'offtake' is used to encompass this diverse lexicon and 'overexploit/ation' when discussing offtake that is known or suspected to be unsustainable. Offtake that is acknowledged in studies but is unquantified or otherwise unreported officially is described as 'hidden'. other quantitative information, on fish or waterbird offtake in wetlands (Table S1 \& S2).

\section{$230 \quad$ Fish offtake}

231 Forty-one relevant studies on fish offtake were collated, of which 24 (59\%) were peer-reviewed.

232 Floodplains were the most common type of wetland identified (63\%) and almost half of the 233 studies were specific to single countries or river basins, of which half of these were site-specific.

234 Most studies (83\%) used the term 'exploit' to describe the offtake of fish, often interchangeably with 'harvest' (73\%). The need for sustainable management of fisheries was referred to in many 
studies (76\%). However, examples of sustainable inland fisheries were only cited in two papers

237 (Ahmed 2008; Hortle and Bamrungrach 2015), while unsustainable inland fisheries were described in four studies (Rana et al. 2009; FAO 2016; Kang et al. 2017; Funge-Smith 2018). Whilst the majority of studies $(76 \%)$ contained some statistics, fewer contained actual data on

240 fish offtake. Offtake by weight, either $\mathrm{kg} \mathrm{ha}^{-1}$ or annual tonnage, was more frequently reported $241(46 \%)$ than by proportion of species taken (12\%). Less than half the studies $(44 \%)$ identified some fish species, and these were generally a list of the most commonly caught species. Artisanal or subsistence fishing was mentioned in many studies (66\%), frequently within the context of the importance of inland fisheries to many people around the world. Subsistence fishing was often identified as an unquantified or hidden offtake. Similarly, recreational or sport fishing was cited quite frequently (46\%) as an unreported offtake, which could have detrimental effects on the sustainability of fisheries. Recreational fishing was usually described in studies pertaining to more economically developed nations. Illegal fishing was a third source of hidden offtake. Thus, available fishing data are unlikely to accurately reflect the true wetland fisheries offtake. Review of FAO data indicated that inland wetland fisheries account for approximately $15 \%$ of all capture fisheries, not including aquaculture (FAO 2016). Global offtake from inland fisheries has been steadily rising since 1950 when national data began to be collated, and in 2016 11.6 million tonnes were taken (FAO 2018b). Over $66 \%$ of this offtake is from Asia, with China taking nearly 2.3 million tonnes (FAO 2018b), representing the world's biggest inland fishery (Funge-Smith 2018). Africa also makes a substantial contribution to global inland fisheries (FAO 2018a).

National offtake data from inland fisheries often neglects to record subsistence activity and lacks valuable information on wetland type and species. A comparison by the World Bank (2012) using eight Asian and African countries estimates that inland fish offtake may be up to 5.9 times greater than officially reported, due partially to subsistence fishing. Lymer et al. (2016) 
estimate the theoretical global inland fisheries offtake to be 6.5 times higher than official data at approximately 72 million tonnes each year, largely due to better estimates of yield and the area type, but for most national statistics this information is not available and it is unclear which wetlands are included. This overlooks the importance of different wetlands for fish and fishers.

266 For example, floodplains are the single largest source of inland fish offtake and likely comprise two thirds of the inland wetland fisheries area (Lymer et al. 2016), yet are not identified in most national statistics. Floodplains may be under-reported and often account for large increases in offtake when they are incorporated into data (Welcomme 2011), such as for Myanmar where annual fish offtake increased from 290,000 to 1.24 million tonnes between 2003 and 2012 (FAO 2016; FAO 2018a) largely because of the inclusion of floodplain fisheries. There is limited data available about the fish species taken from different wetland types, and there also seems to be disparities between the main species reported by national or more local records and those species, if any, collated internationally (e.g. by the FAO).

\section{Case study: Reporting fish offtake in Bangladesh}

277 Bangladesh was selected for analysis because fishing is particularly important to the country and 278 it reports fisheries data relatively well. Over $60 \%$ of households rely on offtake of wild fish from 279 inland wetlands for income, food, or subsistence in Bangladesh (Craig et al. 2004; Hossain and 280 Wahab 2009), the third largest inland capture fishery globally producing 1,048,242 tonnes in 2016 (FAO 2018b). Fish are considered the most affordable and rich source of (animal) protein in Bangladesh (Galib et al. 2009). As a topographically low-lying country, almost half of Bangladesh's territory is covered by inland waters (Hossain and Wahab 2009). During the wet season, lasting 4-6 months each year, seasonal floodplains expand to cover up to $55,000 \mathrm{~km}^{2}$ (38\% of land area) (Hossain and Wahab 2009). During the dry season, the main rivers (Meghna, 
286 Ganges, Jamuna), their tributaries, and canals cover $4797 \mathrm{~km}^{2}(3 \%)$; estuarine areas (incl. the

287 Sundarbans) $5518 \mathrm{~km}^{2}$ (4\%); and large permanent or semi-permanent depressions, known locally 288 as 'beels', amount to $1142 \mathrm{~km}^{2}$ (1\%) (Hossain and Wahab 2009).

289 Fish offtake from wetlands in Bangladesh is relatively well documented in annual 290 yearbooks released by the Government Department of Fisheries (Department of Fisheries 2017), 291 allowing critical comparison of trends. Yearbooks provide information on total fish offtake quantity and by inland wetland type such that change in offtake over time can be assessed (Fig. (Lymer et al. 2016), from which offtake in the last 13 years has fluctuated but overall increased (Fig. 1). Offtake from rivers and estuaries has also grown and there has been a slight increase in offtake from beels (Fig. 1). Additional official information includes fish offtake by district, fish species caught by weight, and percentage of catch per wetland type. Data on subsistence fishing, accounting for $53 \%$ of total offtake or $81 \%$ of offtake from floodplains, is provided separately (e.g., Department of Fisheries 2017). Subsistence fishing in Bangladesh, usually with few restrictions (Mustafa and Brooks 2008), is important especially for a minority of the population who tend to fish smaller fish, often women and children (Craig et al. 2004) and at certain locations (e.g. Dogger beel, which is mostly fished by subsistence fishers (Siddiq et al. 2013)). species-level and comparing across different scales. Over 260 species of fish have been recorded in Bangladeshi inland waters (Rahman et al. 1999). The main groups that are commercially fished include Hilsa shad, carp and catfish, as well as prawns and shrimp (Fig. 2, Table 2) (Craig et al.

307 2004), with the majority of fish taken being consumed, e.g. 77 of the 81 species caught in the 308 Chalan beel are consumed (Galib et al. 2009). Offtake of most fish has increased in recent years (Fig. 2). At national level, data on offtake resolved by species are not readily available, as species

310 data are reported by amalgamated species categories (Table 2) and reporting is likely limited to 
311 the economically important species. Tracking change in offtake of individual species or even of 312 species categories can be difficult, as categories and their species composition have changed over

313 time (Table 2). Similarly, national statistics on species offtake, e.g. for beels, cannot readily be 314 compared to data from regions and individual wetlands (Fig. 3). By aggregating data, potentially 315 valuable information for species or sites is lost. For example, species classified as "major carp" 316 constitute almost $30 \%$ of offtake from beels nationally yet these species are absent or comprise 317 less than 5\% from some sites (Fig. 3a). Studies of individual wetlands often include valuable data 318 on fish diversity, offtake rates, types of fishing gear used and reasons for fishing. Discrepancies 319 when comparing national and regional or individual wetland data are partially caused by 320 inconsistent species classification. An example is the Ashura beel, a 252 ha wetland in north east 321 Bangladesh, where native "other carp" are unreported at national level yet inspection of species 322 records show comprise 30\% of the catch (Fig. 3b) (Mustafa and Brooks 2008). Such data comparison highlights that regionally preferred species may go unmentioned in national statistics or aggregated in the "other fish" category (Fig. 3).

While national statistics show increases in some fish offtakes in Bangladesh, local studies suggest that illegal fishing, use of illegal gear, pollution, wetland loss and degradation and overexploitation threaten the sustainability of wetland offtakes. Declines in fish diversity have been reported at Chalan beel (Galib et al. 2009; Sayeed 2014), Bamal, Salimpur, Kola and Bashukhali (BSKB) beel (Rahman et al. 1999), Goakhola beel (Mustafa and Brooks 2008), and 330 Tanguar Haor (Ramsar Convention 2000). Reported causes of such declines include small331 meshed nets (Galib et al. 2009), poor water quality (Ahmed et al. 2009), hydraulic engineering interfering with migratory species (Halls et al. 1999), and overexploitation of larger species

333 (Rahman et al. 1999; Ahmed 2008; Mustafa and Brooks 2008). 


\section{Waterbird offtake}

336 Forty-one studies were identified on waterbird offtake from wetlands, of which $30(73 \%)$ were

337 peer-reviewed. There was a paucity of information with a global representation, with most studies 338 (73\%) based on a country, flyway, or continent. Where data were available, they were derived 339 mainly from government statistics from more economically developed countries and apparently

340 reflected recreational offtake. Data from less economically developed nations were limited, which may reflect ineffective regulation of bird offtake in these countries even though it is often

342 illegal. In these countries offtake was almost always for subsistence or income generation rather 343 than recreation (UNEP and CMS Secretariat 2014). Offtake was described as 'hunt(ing)' in 344 almost every study (95\%), often used interchangeably with 'harvest(ing)' (66\%), and 345 'exploitation' of birds was also used occasionally (36\%). 'Sustainable' was often applied (61\%) as an aspiration for waterbird offtake, rather than suggesting that it is currently sustainable. There were only three studies (Sodhi et al. 2011; UNEP and CMS Secretariat 2014; Madsen et al. 2015) that reported examples of sustainable bird offtake, with four times as many examples of unsustainable offtake reported. Statistics or estimates of waterbird offtake were found in $73 \%$ of

350 the studies. These included bag counts, illegal offtake and population indicators, and ranged from individual countries to continental estimates. Most studies (66\%) encompassed all waterbirds, although there were eight studies focussed on geese and four on ducks. The most frequently articulated motive for waterbird offtake was for recreation or sport $(59 \%)$ rather than for subsistence (32\%). Hidden offtake through illegal hunting of waterbirds was referred to in $51 \%$ of the studies, although this was generally an acknowledgement that it was taking place, and only five studies presented any data for estimated illegal offtake (Gray and Kaminski 1994; Brochet et al. 2016; BirdLife International 2017b; Brochet et al. 2019; Ilyashenko and Mirande In prep). Counts (or estimates) collected by governments for birds taken by legal hunting are theoretically accessible for 21 European and North American countries. These constitute a 
360 valuable resource, especially for recent years as these statistics are available online, but the 361 national datasets are generally of variable quantity and quality. In Europe, the type of data

362 collected, the species reported, and the temporal extent of the recording, varies greatly. For 363 example, hunting data from Austria extending back to 1983 is available online, however the data 364 are presented in just four broad categories for waterbirds: snipe, ducks, geese and coot (Statistik 365 Austria 1983-2018). Records from the Czech Republic in contrast can list 13 individual species, 366 but the time series is less detailed with many years showing data for only three species (Czech 367 Statistical Office (CZSO) 2008-2018). Some other countries do not appear to collect or make 368 available any official data for bird hunting, such as the UK, making it difficult to assess the 369 sustainability of such offtake. Records of recreational hunting from the USA and Canada are 370 relatively comprehensive, including data on ducks, geese, rails and other species. In the USA, 371 data have been collected since the 1952/53 hunting season, and are currently collated for 41 species by state and flyway, with analyses of sex and age ratio of some species and information on the number of hunters (Raftovich et al. 2016). However, the data depend upon survey 374 information from hunters, which relies on the accuracy of their bird identification. Christensen 375 et al. (2017) found that hunters in Denmark asked to identify between five goose species averaged 76\% accuracy. Some species were more easily identified than others (e.g. Canada goose) and adults were more accurately identified than juveniles.

379 between countries, and support relatively long runs of offtake data in national sets so that 380 temporal trends can be evaluated. The mallard is probably the most hunted waterbird species, especially in more economically developed countries where recreational hunting predominates. National statistics indicate that the offtake of mallards varies greatly between countries and over many years (Fig. 4). Numbers hunted range from a few thousand in Switzerland (Eidgenössische

384 Jagdstatistik 2019) to over five million in the USA (Canadian Wildlife Service Waterfowl 
385 Committee 2015), no doubt related to the populations of mallards and hunters in countries of 386 such contrasting size. However, despite some large peaks and troughs in the numbers of birds

387 hunted over time, all countries show a decrease in offtake in recent decades (Fig. 4). The 388 reduction in mallards taken in the USA in the 1980's may have directly reflected a declining 389 species population at the time, but the decrease in mallards hunted since 2000 is in contrast to an 390 increase in its population (Canadian Wildlife Service Waterfowl Committee 2015). Another 391 explanation is that the number of people hunting has decreased, which may be the case in Canada 392 where the number of waterbird hunters has fallen sharply since the mid-1970's (Gendron and 393 Smith 2017), mirroring the decrease in mallards taken. However, in Hungary the number of 394 recreational hunters (as opposed to professional hunters) has quite steadily increased from about 39519,000 in 1960 to 58,000 in 2016 (Sándor et al. 2017), yet the number of mallards taken has 396 fallen since 1989 despite a relatively stable European population (BirdLife International 2017a).

397 Evidently, trends in offtake over time and between countries are complicated by indirect human 398 factors, such as conservation policies and social changes.

\section{Case study: Waterbird offtake by indigenous and recreational hunters in Canada}

401 Canada was selected for analysis because it is estimated to support almost a quarter of the global wetland area, not including rivers and lakes (Bridgham et al. 2006), and has a tradition of hunting waterbirds. Wetlands cover approximately 1.3 million $\mathrm{km}^{2}$, or $13 \%$ of Canada's terrestrial area

404 (Environment and Climate Change Canada 2016). Its diverse resource of over 90,000 wetlands 405 (Lehner and Döll 2004a; Lehner and Döll 2004b) occurs in prairies, boreal forest, along coastlines and in the tundra, and includes various types such as marshes, swamps and open water,

407 although peatland bogs and fens dominate (Bridgham et al. 2006).

Most of the waterbird species taken in Canada are migratory (Table 3; Canadian Wildlife

409 Service Waterfowl Committee 2017). Populations of most North American migratory birds have 
410 been declining since the 1980's (Kirby et al. 2008), although those of some species, such as

411 Canada goose, are increasing (Sauer et al. 2013). Offtake by hunting is generally considered one

412 of the causes of migratory species declines, such as in the Middle East and to a lesser extent

413 Europe (Kirby et al. 2008), but the impact of offtake on North American migratory species

414 overall is unknown (UNEP and CMS Secretariat 2014).

415 Canada's 172 migratory waterbird species (UNEP and CMS Secretariat 2014) are hunted

416 by both recreational hunters and indigenous people. Canada offers a revealing perspective on

417 waterbird offtake because of these two very different hunter communities. A larger proportion of 418 indigenous Inuit hunt, between 30\% (Joint Secretariat - Inuvialuit Settlement Region 2003) and

$41970 \%$ (Berkes et al. 1994; Wein and Freeman 1995), whereas less than $0.5 \%$ of the general 420 population take part in recreational hunting (Joint Secretariat - Inuvialuit Settlement Region 421 2003). Wildfowl (geese, swans and ducks) are the most frequently hunted by number of individuals taken by indigenous peoples (Wein and Freeman 1995; Usher 2002). Furthermore, indigenous hunters tend to take more individuals compared to recreational hunters (Fig. 5); for 424 example, approximately 56,000 Canada geese were taken by 1,500 Omushkego Cree, while 42583,900 geese were taken by over 82,500 recreational hunters in 1993 in Ontario (Berkes et al. 426 1994).

Recreational hunters are required to obtain permits, so detailed hunting records of 428 migratory birds are available in annual reports (e.g., Canadian Wildlife Service Waterfowl 429 Committee 2017). Records on hunting have been collected by state and species, for some dating 430 back as far as 1974, and information on population trends are available for 40 species (e.g., 431 Canadian Wildlife Service Waterfowl Committee 2015). Less detail is generally known about offtake by indigenous people as most of those with such status are not required to obtain a licence nor are they restricted to particular seasons and bag counts, although hunting is restricted within

434 the tribal territory (Truesdale and Brooks 2017). Strong hunting traditions are maintained in 
435 Canada's indigenous populations as many live at least a partial subsistence way of life (Peloquin and Berkes 2009). Although indigenous people make up less than 5\% of the population, approximately $35 \%$ of hunting in Canada is for subsistence purposes, much higher than the $4 \%$ in the United States and many European Countries (UNEP and CMS Secretariat 2014).

Information and insights on offtake by Canada's indigenous people can be gleaned from ethnographic studies and surveys (Berkes et al. 1994; Joint Secretariat - Inuvialuit Settlement Region 2003; Peloquin and Berkes 2009). A detailed survey of the offtake by Inuvialuit, Inuits of artic western Canada, from 1988 to 1997 provides data on the month and quantity of each species hunted, and the number of hunters (Joint Secretariat - Inuvialuit Settlement Region 2003) (Fig. 5a). When compared to the offtake by recreational hunters in the Northwest Territories (Fig. $5 b)$, there are substantial differences in species composition. Snow goose, greater white-fronted goose and eider ducks were the largest counts year-on-year for indigenous subsistence hunters, whereas recreational hunters favoured mallard, snow goose, wigeon (a dabbling duck) and scaup (a diving duck) (Fig. 5). Inuvialuit hunters took a much wider variety of species than recreational hunters (Table 3). This is partially because the Inuvialuit settlements are generally coastal and therefore have access to a greater range of sea duck species, also because recreational hunters are prohibited to take some species (e.g. swans), and because the strong taste of some species (e.g. long-tailed duck) makes them less desirable to recreational hunters (Canadian Wildlife Service Waterfowl Committee 2015).

Historically in Canada, migratory waterbird hunting was seasonal and likely sustainable (Tsuji and Nieboer 1999). Migratory waterbirds were easily obtained when species returned to the same locations each year (Kristensen 2011). For example, Canada geese were traditionally harvested by the Cree of Northern Ontario when abundant in late spring (Tsuji and Nieboer 1999). As hunting and refrigeration technology advanced, diets changed and traditional knowledge and codes of conduct that prevented overexploitation have been lost, such that 
460 subsistence hunting should no longer be assumed to be sustainable. Moreover, contemporary

461 pressures in addition to hunting may interact to impact upon waterbird populations. For example,

462 continuous but incremental changes in climate as well as local hydroelectric development are

463 understood to be the reasons for decreases in geese numbers rather than overexploitation at James

464 Bay, Quebec (Peloquin and Berkes 2009).

465 To sustainably manage waterbird populations, comparable information on all offtake and 466 hunters is crucial, including indigenous subsistence activity. Harvesting information was

467 collected from indigenous people in Canada for over 40 years (Usher 2002; Joint Secretariat 468 Inuvialuit Settlement Region 2003), usually using questionnaires and/or interviews, but these

469 various studies were not continued. While there is no evidence of a general lack of participation, 470 women and children's harvests could be under-reported (Berkes et al. 1994), some hunters 471 declined to be interviewed or became fatigued (Joint Secretariat - Inuvialuit Settlement Region 472 2003), and some indigenous peoples groups witheld detailed information for ethical reasons or 473 to protect traditional knowledge (Benoit 2007). Current officially collated records are therefore 474 probably only capturing some of the waterbird offtake in Canada; examples include the Brant 475 goose of which 'a few thousand' are harvested by subsistence hunters, although the reported 476 harvest is only in the hundreds (Canadian Wildlife Service Waterfowl Committee 2015), and 477 Common eider, for which subsistence offtake is not included (Merkel and Barry 2008). Trends 478 from the Maritimes region in southeast Canada suggest a decline in both indigenous and 479 recreational hunting between 1993 and 2004, although the decline is less steep for indigenous 480 peoples (Benoît 2007). However, contemporary published research on indigenous harvesting is 481 lacking, which would be important to assess recent trends in waterbird offtake.

482 


\section{Conclusions}

484 Wetlands globally provide extremely valuable provisioning services and are biologically diverse.

485 Offtake represents a pressure on wetlands that has not been evaluated, but this systematic review 486 of the literature and data sources revealed the following critical issues for fish and waterbirds.

Semantics

There is a diverse lexicon associated with offtake in the literature and this is applied inconsistently between taxa. For example, while similarities were found between fish and bird taxa in the ubiquitous use of the term 'harvest', the term 'exploit' appeared to have different connotations and frequency of use. Within fishery studies, exploit was used often and in general to describe fish as a resource, unless over-exploitation was explicitly stated. Within studies of waterbird offtake, exploit was used less frequently and was more likely to have a negative association.

496

497

Data availability and quality

498

There is a paucity of data globally for waterbird offtake, and especially for less economically developed countries, while fishing data from inland waters are collected globally by the FAO (e.g. FAO 2018a). Nearly all data for both fish and bird offtake used in studies are derived from government sources. However, data quality for both taxa are variable with species or site

502 information lacking, including for fish offtake from floodplains which are by far the most important inland fisheries (Lymer et al. 2016). Long-term fish and bird records are often incomplete or inconsistent, making monitoring of offtake and populations difficult. Information on the type of wetland providing the offtake is also frequently absent, potentially hampering 
conservation priorities and policies. Where data are absent, for example when Governments fail to collect or publish data, there is a reliance on estimates for larger-scale geographic areas.

509 Disparities between records

510 Offtake records collected locally, nationally and internationally are frequently incomparable 511 because they are not reported consistently. The aggregation of data for national statistics is 512 common, such as amalgamating carp species in fisheries and ducks and geese for waterbirds, and 513 may be a response to variable data recording. However, it can lead to the loss of important 514 information, such as hunting pressure on individual species, some of which may be rare.

516 Hidden offtake and by-catch

517 Hidden offtake, which is unreported and frequently illegal, is widely recognised as a problem. It 518 hinders obtaining accurate values for offtake and official statistics are highly likely to be a 519 substantial undercount. Subsistence, recreational or sports fishing, and fishing by illegal methods, are the main sources of hidden offtake for fish in wetlands. Illegal shooting and trapping are the main activities for hidden offtake of birds. Estimates of the amount of hidden offtake for fish and birds from wetlands are not available, but clearly this may be a serious pressure on species. Official figures suggest that legal fish offtake is increasing (FAO 2018b) while migratory waterbirds are declining (Kirby et al. 2008), even if the hunting of waterbirds in North America at least may be decreasing (U.S. Department of the Interior et al. 2016). review did not specifically include this issue, it is known that the by-catch of fishing may include birds, turtles and macroinvertebrates (Davies et al. 2009) and that by-catch represents a threat to vertebrate species at risk of extinction (Ripple et al. 2019). 
531 Socio-economic and cultural factors

532 Reported offtake of birds is most frequently for the purpose of sport or recreation, while fish 533 offtake (that was not commercial) is mainly to support subsistence fishers. This difference

534 reflects the trend for waterbird data to originate from more economically developed countries 535 with studies on fish offtake more likely from less economically developed nations, where the 536 largest inland fisheries tend to be found. Within countries, different communities may target 537 different species for offtake, based upon cultural traditions, and differentially contribute to 538 official data reporting. Such socio-economic and cultural factors may make comparisons between 539 taxa or within countries challenging, and may require participatory methods to gather necessary 540 information (e.g. Wiber et al. 2004).

542 Sustainability

543 Studies of fish and birds frequently refer to the need for sustainable management of fishing and 544 hunting, but unsustainable practices are more likely to be indicated in the literature than 545 sustainable ones. Nevertheless, authors are inclined to show caution in suggesting current offtake 546 is unsustainable, most likely due to underreporting and incomplete data on offtake, along with a 547 lack of reliable population statistics, making it difficult to accurately assess sustainability. The 548 overexploitation of species could clearly affect population viability and risk extinction, and it

549 could also affect ecosystem functioning and services. The loss of provisioning services in 550 wetlands will reduce food availability and income, and may impact income from tourism and 551 recreation, affecting some of the most impoverished people in less economically developed 552 countries (Millennium Ecosystem Assessment 2005). Wetland animals may be particularly at 553 risk from overexploitation due to the fragmented and isolated nature of many wetlands, which 
makes it difficult for some species to move between them (Brinson and Malvárez 2002) and maintain a viable population (He et al. 2017). Moreover, many waterbirds are migratory, moving between countries along transcontinental corridors known as flyways. National datasets do not capture all offtake along the flyway, leading to a lack of integrated understanding and management of international bird populations. Management is further complicated by the

559 diversity of customs and cultures represented along the flyway, and by the different legislation and policies on hunting practised by countries, making sustainable offtake of migratory bird species particularly problematic (Madsen et al. 2015).

Examples of sustainable offtake for fish and waterbirds are rare in the literature. The Svalbard-breeding population of the pink-footed goose has an internationally coordinated adaptive hunting management framework along its relatively short Northern European migratory flyway (Clausen et al. 2017). Evidence suggests that offtake has not affected population growth but still caution is recommended due to variable data availability in countries along the migratory corridor and potential population inertia in long-lived species such as geese (Clausen et al. 2017). Management plans may provide a useful tool for control of offtake to achieve sustainability targets. For example, the North American Waterfowl Management Plan, which implemented sustainable harvesting and wetland protection and restoration programs across Canada, USA and Mexico, has probably helped reverse the waterbird population declines of the 1980's by restricting hunting to allow recovery (North American Waterfowl Management Plan 2012).

Further research

575 An accurate evaluation of the global offtake from wetlands requires data for species and sites 576 recorded consistently over many years; it is evident from this review that, other than for a very 577 few cases, such information is lacking. This study has shown that reliable data on wetland offtake 578 is at best patchy over space and time and at worst absent, similar to terrestrial wild animal offtake 
579 (e.g. Ingram et al. 2015; Joppa et al. 2016). Data gaps and insufficiencies are often due to 580 unreported and illegal offtake, or inconsistent or aggregated reporting, while comparison between

581 different communities and countries is difficult when data are not standardised. One solution to 582 data gaps and variabilities is modelling, based on estimates extrapolated from known data sources 583 (e.g. as done for terrestrial offtake Ziegler et al. 2016; Benítez-López et al. 2019). Thus, where 584 data are available, these could be used to model offtake in other areas and over time periods 585 where data are scarce, and thereby used to not only estimate global offtake of for wetlands but also to predict offtake in the future. Modelling may also allow integration of data on other 587 pressures that interact with offtake to pose cumulative or synergistic threats to species. In this 588 review, for example, specific studies were found that reported waterbird deaths from poisoning 589 by lead shot as an indirect consequence of hunting (Andreotti et al. 2018), but these were not included in national statistics for offtake. Further research to assess the global offtake from wetlands is overdue because current

592 levels and trends are not known, although this study suggests wild fish offtake may be increasing 593 and offtake represents a potentially significant pressure on species and biodiversity. Given the 594 importance of wetland offtake for provisioning services, the sustainable management of wetland 595 resources is vital to prevent biodiversity loss and food poverty to some of the world's most 596 vulnerable people (Millennium Ecosystem Assessment 2005). Better information on offtake 597 would support monitoring and refinement of global conservation and development policies, such 598 as the Aichi Biodiversity targets (UNEP and CBD 2010) and Sustainable Development Goals 599 (UN General Assembly 2015), as well as facilitate better management plans, species and site 600 protection, and restoration initiatives for wetlands.

601 
602 Acknowledgements This research was supported by the University of Brighton and University 603 of Sussex Collaborative Research Fund. We are grateful to Dr Nick Davidson and Rob McInnes 604 who provided expert advice during the research.

605

606 Conflict of interest The authors declare that they have no conflict of interest. 
609 Fig. 1 Total fisheries offtake from beels (black), rivers and estuaries (dark grey) and floodplains

610 (light grey) in Bangladesh between 2003 and 2017. Bangladesh fisheries yearbooks provide data

611 for Kaptai Lake and Sundarbans as inland waters; these are excluded here as Kaptai Lake is man-

612 made and the Sundarbans are saline mangrove systems. Data from Department of Fisheries $613(2004-17)$

614

615 Fig. 2 Offtake of the major groups of fish and crustaceans in rivers and estuaries of Bangladesh 616 from 2003 to 2017. Data from Department of Fisheries (2004-17). See Table 2 for species 617 information

619 Fig. 3 Comparisons of fisheries offtake (aggregated over 1997-2002) between (a) all beels in 620 Bangladesh (black bars, data from Department of Fisheries (2004) and three individual beels, 621 Ashura (dark grey), Diskshi (light grey) and Goakhola (white) (data from Mustafa and Brooks 622 (2008), with species grouped by national categorization from Department of Fisheries (DOF), and (b) categories for Ashura beel containing all species taken as assigned to national DOF categories by the authors (black bars) and species officially reported in national DOF categories (white bars), for which many species are aggregated into "other fish". Note: no major carp species were taken at this location. Species lists by DOF categories are shown in Table 2

628 Fig. 4 Number of mallards taken according to national hunting statistics for (a) Canada and (b) 629 USA (Canadian Wildlife Service Waterfowl Committee 2015), (c) Denmark (Danish Centre for 
630 Environment and Energy 2019), (d) Switzerland (Eidgenössische Jagdstatistik 2019) and (e)

631 Hungary (Sándor et al. 2017)

632

633 Fig. 5 Offtake of waterbirds (number of individuals) from 1988 to 1997 in Canada by (a) Inuit 634 indigenous hunters in the Inuvialuit settlement region (Joint Secretariat - Inuvialuit Settlement 635 Region 2003) and (b) recreational hunters in the Northwest Territory (Government of Canada 636 2017). Species lists by categories are shown in Table 3 
637 Table 1 Target words used in Web of Science and Google Scholar searches

\begin{tabular}{llll}
\hline Offtake theme & Wetland theme & Fish theme & Waterbird theme \\
\hline Bag(s) & Wetland(s) & Fish(ing/er/ery) & Waterbird(s) \\
Count(s) & Floodplain(s) & Inland & Wader(s) \\
Offtake & Swamp(s) & Stock & Duck(s) \\
Harvest(ing) & Pothole & Recreation(al) & Geese \\
Exploit(ation) & & Sport & Anatidae \\
(Un)sustainable & & & Waterfowl \\
Hunt(ing/er) & & Flyway(s) \\
Subsistence & & \\
(Il)legal & &
\end{tabular}

638

639

640 Table 2 Fish species categorised by the Department of Fisheries yearbooks for Bangladesh.

641 Exotic carp are not recorded in rivers and estuaries, while Hilsa shad is not found in beels and

642 floodplains. This table uses the categories as represented in the 2016/17 yearbook, although

643 species have been moved between categories, and categories have been added or removed, since

644 2003/04. Data from Department of Fisheries (2017)

\begin{tabular}{lll}
\hline Category & Common names (Bengali) & Scientific names \\
\hline Major carp & Rui & Labeo rohita \\
& Catla & Catla catla \\
& Mrigal & Cirrhinus mrigala \\
Other carp & Kalibaus & Labeo calbasu \\
& Bata & Labeo bata
\end{tabular}


Gonia

Exotic (non-native) carp Silver

Grass

Common or Mirror

Big head

Black

Catfish*

Snakeheads

Snakeheads

Live fish\#

Other inland fish

$\begin{array}{ll}\text { Live fish\# } & \text { Koi } \\ & \text { Shingi } \\ & \text { Magur } \\ \text { Other inland fish } & \text { Includes: } \\ & \text { Sarpunti } \\ & \text { Thai sharpunti } \\ & \text { Punti spp. } \\ & \text { Chapila } \\ & \text { Tengra } \\ & \text { Pabda } \\ \text { Baim }\end{array}$

Labeo gonius

Hypophthalmichthys molitrix

Ctenopharyngodon idella

Cyprinus carpio

Hypophthalmichthys nobilis

Mylopharyngodon piceus

Pangasius pangasius

Wallago attu

Sperata aor

Silonia silondia

Rita rita

Channa marulius

Channa striatus

Channa punctatus

Anabas testudineus

Clarias batrachus

Heteropneustes fossilis

Includes:

Systomus sarana

Barbonymus gonionotus

Puntius spp.

Gudusia chapra

Mystus spp.

Ompak pabda

Mastacembelus spp. 
Mola

Hilsa shad

Large prawns \&

Ilish

Bagda

shrimp +

Galda,

Harina

Chaka

Small prawn \& shrimp+ Includes:

small Chingri
Amblypharyngodon mola

Tenualosa ilisha

Penaeus monodon

Macrobrachium rosenbergii

Metapenaeus monoceros

Fenneropenaeus indicus

Includes:

Decapoda

645 *from 2013/14 catfish have been divided into two categories: Pangas and other catfish, which

646 includes four other species

647 \# fish that are sold alive (Craig et al. 2004)

$648+$ the terms prawn and shrimp have been used interchangeably since 2003/04

649

650

651 
652 Table 3 Wildfowl and other waterbird species taken by recreational and Inuvialuit hunters in 653 Canada. Information from Joint Secretariat - Inuvialuit Settlement Region (2003) and 654 Government of Canada (2017)

\begin{tabular}{|c|c|c|c|c|}
\hline \multirow[t]{2}{*}{ Categories } & \multicolumn{2}{|l|}{ Species } & \multicolumn{2}{|l|}{ Offtake } \\
\hline & Common name & Scientific name & Recreational & Inuvialuit \\
\hline \multirow[t]{5}{*}{ Geese } & Canada & Branta canadensis & $\mathrm{x}$ & $\mathrm{x}$ \\
\hline & Snow & Chen caerulescens & $\mathrm{x}$ & $\mathrm{x}$ \\
\hline & Greater white-fronted & Anser albifrons & $\mathrm{x}$ & $\mathrm{x}$ \\
\hline & Brant & Branta bernicla & & $\mathrm{x}$ \\
\hline & Ross's & Chen rossii & & $\mathrm{x}$ \\
\hline Mallard & Mallard & Anas platyrhynchos & $\mathrm{x}$ & $\mathrm{x}$ \\
\hline Other dabbling & Northern pintail & Anas acuta & $\mathrm{x}$ & $\mathrm{x}$ \\
\hline \multirow[t]{3}{*}{ ducks } & Green-winged teal & Anas crecca & $\mathrm{x}$ & $\mathrm{x}$ \\
\hline & American wigeon & Anas americana & $\mathrm{x}$ & $\mathrm{x}$ \\
\hline & Shoveler & Anas clypeata & $\mathrm{x}$ & $\mathrm{x}$ \\
\hline Inland diving & Canvasback & Aythya valisineria & $\mathrm{x}$ & $\mathrm{x}$ \\
\hline ducks & Scaup sp. & Aythya sp. & $\mathrm{x}$ & $\mathrm{x}$ \\
\hline Eider and other & Eider sp. & Somateria sp. & $\mathrm{x}$ & $\mathrm{x}$ \\
\hline \multirow[t]{4}{*}{ sea ducks } & Scoter sp. & Melanitta sp. & $\mathrm{x}$ & $\mathrm{x}$ \\
\hline & Goldeneye sp. & Bucephala sp. & $\mathrm{x}$ & $\mathrm{x}$ \\
\hline & Long-tailed duck & Clangula hyemalis & & $\mathrm{x}$ \\
\hline & Merganser sp. & Mergus sp. & & $\mathrm{x}$ \\
\hline \multirow[t]{2}{*}{ Swans } & Trumpeter & Cygnus buccinator & & $\mathrm{x}$ \\
\hline & Tundra & Cygnus columbianus & & $\mathrm{x}$ \\
\hline
\end{tabular}


Other unspecified Cygnus spp. $\quad \mathrm{x}$

Other Sandhill crane $\quad$ Grus canadensis

$\begin{array}{lll}\text { waterbirds } \quad \text { Loon sp. } & \text { X }\end{array}$

655

656 


\section{References}

658

659

660

661

662

663

664

665

666

667

668

669

670

671

672

673

674

675

676

677

678

679

680

Ahmed, G. U., M. N. Akter, S. A. Nipa \& M. M. Hossain, 2009. Investigation on health condition of a freshwater eel, Monopterus cuchia from Ailee beel, Mymensingh, Bangladesh. Journal of the Bangladesh Agricultural University 7: 421-426.

Ahmed, M. S., 2008. Assessment of fishing practices on the exploitation of the Titas floodplain in Brahmanbaria, Bangladesh. Turkish Journal of Fisheries and Aquatic Sciences 8: 329334.

Andreotti, A., V. Guberti, R. Nardelli, S. Pirrello, L. Serra, S. Volponi \& R. E. Green, 2018. Economic assessment of wild bird mortality induced by the use of lead gunshot in European wetlands. Science of the Total Environment 610-611: 1505-1513.

Batzer, D. P. \& R. R. Sharitz, 2014. Ecology of freshwater and estuarine wetlands. University of California Press, Berkeley, USA.

Benítez-López, A., L. Santini, A. M. Schipper, M. Busana \& M. A. J. Huijbregts, 2019. Intact but empty forests? Patterns of hunting-induced mammal defaunation in the tropics. PLOS Biology 17: e3000247.

Benoit, A. R., 2007. Aboriginal harvest of waterfowl in the Maritimes. Technical Report Series No. 488. Canadian Wildlife Service, Atlantic Region Sackville.

Berkes, F., P. J. George, R. J. Preston, A. Hughes, J. Turner \& B. D. Cummins, 1994. Wildlife Harvesting and Sustainable Regional Native Economy in the Hudson and James Bay Lowland, Ontario. Arctic 47: 350-360.

BirdLife International, 2017a. European birds of conservation concern: populations, trends and national responsibilities. Birdlife International, Cambridge, UK.

BirdLife International, 2017b. Review of illegal killing and taking of birds in Northern and Central Europe and the Caucasus. BirdLife International, Cambridge, UK, 74. 
Boere, G. C. \& T. Piersma, 2012. Flyway protection and the predicament of our migrant birds: A critical look at international conservation policies and the Dutch Wadden Sea. Ocean \& Coastal Management 68: 157-168.

Brashares, J. S., B. Abrahms, K. J. Fiorella, C. D. Golden, C. E. Hojnowski, R. A. Marsh, D. J. McCauley, T. A. Nunez, K. Seto \& L. Withey, 2014. Wildlife decline and social conflict. Science 345: 376-378.

Bridgham, S. D., J. P. Megonigal, J. K. Keller, N. B. Bliss \& C. Trettin, 2006. The carbon balance of North American wetlands. Wetlands 26: 889-916.

Brinson, M. M. \& A. I. Malvárez, 2002. Temperate freshwater wetlands: types, status, and threats. Environmental Conservation 29: 115-133.

Brochet, A.-L., W. Van Den Bossche, S. Jbour, P. K. Ndang'Ang'A, V. R. Jones, W. A. L. I. Abdou, A. R. Al- Hmoud, N. G. Asswad, J. C. Atienza, I. Atrash, N. Barbara, K. Bensusan, T. Bino, C. Celada, S. I. Cherkaoui, J. Costa, B. Deceuninck, K. S. Etayeb, C. Feltrup-Azafzaf, J. Figelj, M. Gustin, P. Kmecl, V. Kocevski, M. Korbeti, D. Kotrosan, J. Mula Laguna, M. Lattuada, D. Leitao, P. Lopes, N. Lopez-Jimenez, V. Lucic, T. Micol, A. Moali, Y. Perlman, N. Piludu, D. Portolou, K. Putilin, G. Quaintenne, G. RamadanJaradi, M. Ruzic, A. Sandor, N. Sarajli, D. Saveljic, R. D. Sheldon, T. Shialis, N. Tsiopelas, F. Vargas, C. Thompson, A. Brunner, R. Grimmett \& S. H. M. Butchart, 2016. Preliminary assessment of the scope and scale of illegal killing and taking of birds in the Mediterranean. Bird Conservation International 26: 1-28.

Brochet, A.-L., W. Van Den Bossche, V. R. Jones, H. Arnardottir, D. Damoc, M. Demko, G. Driessens, K. Flensted, M. Gerber, M. Ghasabyan, D. Gradinarov, J. Hansen, M. Horvath, M. Karlonas, J. Krogulec, T. Kuzmenko, L. Lachman, T. Lehtiniemi, P. Lorge, U. Lötberg, J. Lusby, G. Ottens, J.-Y. Paquet, A. Rukhaia, M. Schmidt, P. Shimmings, A. Stipnieks, E. Sultanov, Z. Vermouzek, A. Vintchevski, V. Volke, G. Willi \& S. H. M. 

Butchart, 2019. Illegal killing and taking of birds in Europe outside the Mediterranean: assessing the scope and scale of a complex issue. Bird Conservation International 29: 1040.

Burkhead, N. M., 2012. Extinction Rates in North American Freshwater Fishes, 1900-2010. Bioscience 62: 798-808.

711

Canadian Wildlife Service Waterfowl Committee, 2015. Population Status of Migratory Game Birds in Canada: November 2015. Environment and Climate Change Canada, Gatineau.

Canadian Wildlife Service Waterfowl Committee, 2017. Population Status of Migratory Game Birds in Canada: November 2017. Environment and Climate Change Canada, Gatineau.

Christensen, T. K., J. Madsen, T. Asferg, J. P. Hounisen \& L. Haugaard, 2017. Assessing hunters' ability to identify shot geese: implications for hunting bag accuracy. European Journal of Wildlife Research 63: 20.

Clausen, K. K., T. K. Christensen, O. M. Gundersen, J. Madsen \& D. Thompson, 2017. Impact of hunting along the migration corridor of pink-footed geese Anser brachyrhynchus implications for sustainable harvest management. Journal of Applied Ecology 54: 15631570.

Cooke, S. J., E. H. Allison, T. D. Beard, Jr., R. Arlinghaus, A. H. Arthington, D. M. Bartley, I. G. Cowx, C. Fuentevilla, N. J. Leonard, K. Lorenzen, A. J. Lynch, V. M. Nguyen, S. J. Youn, W. W. Taylor \& R. L. Welcomme, 2016. On the sustainability of inland fisheries: Finding a future for the forgotten. Ambio 45: 753-764.

Costanza, R., R. de Groot, P. Sutton, S. van der Ploeg, S. J. Anderson, I. Kubiszewski, S. Farber \& R. K. Turner, 2014. Changes in the global value of ecosystem services. Global Environmental Change 26: 152-158. 
Covich, A. P., M. A. Palmer \& T. A. Crowl, 1999. The role of benthic invertebrate species in freshwater ecosystems - Zoobenthic species influence energy flows and nutrient cycling. Bioscience 49: 119-127.

Craig, J. F., A. S. Halls, J. J. F. Barr \& C. W. Bean, 2004. The Bangladesh floodplain fisheries. Fisheries Research 66: 271-286.

Czech Statistical Office (CZSO), 2008-2018. Basic Data on Hunting Grounds, Game Stock and Hunting. Czech Statistical Office (CZSO), Prague. Accessed 6 June 2018.

Danish Centre for Environment and Energy, 2019. Danish Bag Statistics. Danish Centre for Environment and Energy, Aarhus University. http://fauna.au.dk/en/hunting-and-gamemanagement/bag-statistics/statistics-online-since-1941/. Accessed 6 June 2018.

Davidson, N. C. \& C. M. Finlayson, 2018. Extent, regional distribution and changes in area of different classes of wetland. Marine and Freshwater Research 69: 1525-1533.

Davies, R. W. D., S. J. Cripps, A. Nickson \& G. Porter, 2009. Defining and estimating global marine fisheries bycatch. Marine Policy 33: 661-672.

de Groot, R., L. Brander, S. van der Ploeg, R. Costanza, F. Bernard, L. Braat, M. Christie, N. Crossman, A. Ghermandi, L. Hein, S. Hussain, P. Kumar, A. McVittie, R. Portela, L. C. Rodriguez, P. ten Brink \& P. van Beukering, 2012. Global estimates of the value of ecosystems and their services in monetary units. Ecosystem Services 1: 50-61.

Department of Fisheries, 2004. Fishery statistical yearbook of Bangladesh 2003-04, vol 21. Fisheries Resources Survey System (FRSS), Department of Fisheries Bangladesh, Ministry of Fisheries and Livestock, Government of the People's Republic of Bangladesh.

Department of Fisheries, 2004-17. Yearbook of fisheries statistics of Bangladesh 2003-04 to 2016-17, vol 21-34. Fisheries Resources Survey System (FRSS), Department of Fisheries 

of Bangladesh.

755

756

757

758

759

760

761

762

763

764

765

766

767

768

769

770

771

Department of Fisheries, 2017. Yearbook of fisheries statistics of Bangladesh 2016-17, vol 34.

Fisheries Resources Survey System (FRSS), Department of Fisheries Bangladesh, Ministry of Fisheries and Livestock, Government of the People's Republic of Bangladesh.

Duda, M. P., K. E. Hargan, N. Michelutti, L. E. Kimpe, N. Clyde, H. G. Gilchrist, M. L. Mallory, J. M. Blais \& J. P. Smol, 2018. Breeding eider ducks strongly influence subarctic coastal pond chemistry. Aquatic Sciences 80: 40.

Eidgenössische Jagdstatistik, 2019. Die neue Schweizerische Jagdstatistik. https://www.uzh.ch/wild/static/jagdstatistik/?page=home. Accessed 22 March 2019.

Environment Agency, 2019. Annual summary of rod licence sales. https://data.gov.uk/dataset/2b303513-bc81-4bef-880f-8a587db9b3a1/annual-summaryof-rod-licence-sales. Accessed 22 March 2019.

Environment and Climate Change Canada, 2016. Canadian Environmental Sustainability Indicators: Extent of Canada's Wetlands. Environment and Climate Change Canada, Gatineau.

FAO, 2016. The State of World Fisheries and Aquaculture 2016. Contributing to food security and nutrition for all. Food and Agriculture Organization of the United Nations, Rome.

FAO, 2018a. FAO Yearbook. Fishery and Aquaculture Statistics 2016. Food and Agriculture Organization of the United Nations, Rome.

FAO, 2018b. The State of World Fisheries and Aquaculture 2018 - Meeting the sustainable development goals. Food and Agriculture Organization of the United Nations, Rome. 
FAO Fisheries and Aquaculture Department, 2016. Fisheries and aquaculture software. FishStatJ - software for fishery statistical time series. Food and Agriculture Organization of the United Nations. http://www.fao.org/fishery/. Accessed 9 January 2019.

Funge-Smith, S. J., 2018. Review of the state of world fishery resources: inland fisheries. Food and Agriculture Organization of the United Nations, Rome.

Galib, S. M., M. A. Samad, A. B. M. Mohsin, F. A. Flowra \& M. T. Alam, 2009. Present status of fishes in the Chalan Beel the largest beel wetland of Bangladesh. International Journal of Animal and Fisheries Science 2: 214-218.

Gendron, M. H. \& A. C. Smith, 2017. National Harvest Survey web site. Bird Populations Monitoring, National Wildlife Research Centre, Canadian Wildlife Service, Ottawa, Ontario.

Government of Canada, 2017. National harvest survey data query. Government of Canada,. https://wildlife-species.canada.ca/harvest-survey/P001/A001/?lang=e. Accessed 19 September 2018 .

Gray, B. T. \& R. M. Kaminski, 1994. Illegal Waterfowl Hunting in the Mississippi Flyway and Recommendations for Alleviation. Wildlife Monographs 127: 3-60.

Green, A. J. \& J. Elmberg, 2014. Ecosystem services provided by waterbirds. Biological Reviews 89: $105-122$.

Green, A. J., K. M. Jenkins, D. Bell, P. J. Morris \& R. T. Kingsford, 2007. The potential role of waterbirds in dispersing invertebrates and plants in arid Australia. Freshwater Biology 53: $380-392$.

Halls, A. S., D. D. Hoggarth \& K. Debnath, 1999. Impacts of hydraulic engineering on the dynamics and production potential of floodplain fish populations in Bangladesh. Fisheries Management and Ecology 6: 261-285. 
He, F., V. Bremerich, C. Zarfl, J. Geldmann, S. D. Langhans, J. N. W. David, W. Darwall, K. Tockner, S. C. Jähnig \& G. Iacona, 2018. Freshwater megafauna diversity: Patterns, status and threats. Diversity and Distributions 24: 1395-1404.

He, F., C. Zarfl, V. Bremerich, A. Henshaw, W. Darwall, K. Tockner \& S. C. Jähnig, 2017. Disappearing giants: a review of threats to freshwater megafauna. Wiley Interdisciplinary Reviews: Water 4: e1208.

Hortle, K. G. \& P. Bamrungrach, 2015. Fisheries Habitat and Yield in the Lower Mekong Basin. MRC Technical Paper No 47. Phnom Penh, Cambodia, 80.

Hossain, M. A. R. \& M. A. Wahab, 2009. The diversity of Cypriniforms throughout Bangladesh: Present status \& conservation challenges. In Tepper, G. H. (ed) Species Diversity and Extinction. Nova Science Publisher, New York, 143-182.

Ilyashenko, E. \& C. Mirande, In prep. Illegal take including hunting, trapping, and poisoning, in Crane Conservation Strategy. In Mirande, C. \& J. Harris (eds) Crane Conservation Strategy. vol UNEP/CMS/PPWG2/Doc.5. International Crane Foundation, Baraboo, Wisconsin, USA.

Ingram, D. J., L. Coad, C. Ben, N. F. Kumpel, T. Breuer, J. E. Fa, D. J. C. Gill, F. Maisels, J. Schleicher, E. J. Stokes, G. Taylor \& J. P. W. Scharlemann, 2015. Indicators for wild animal offtake: methods and case study for African mammals and birds. Ecology and Society 20: 10 .

IUCN, 2018. The IUCN Red List of Threatened Species. Version 2018-2.

Jäch, M. A. \& M. Balke, 2007. Global diversity of water beetles (Coleoptera) in freshwater. Hydrobiologia 595: 419-442.

Joint Secretariat - Inuvialuit Settlement Region, 2003. Invialuit Harvest Study: Data and methods report 1988-1997. Environment Canada, Canadian Wildlife Service, Fisheries and Oceans, Inuvik NT. 
Joppa, L. N., B. O'Connor, P. Visconti, C. Smith, J. Geldmann, M. H. Mann, J. E. M. Watson, S. H. M. Butchart, M. Virah-Sawmy, B. S. Halpern, S. E. Ahmed, A. Balmford, W. J. Sutherland, M. Harfoot, C. Hilton-Taylor, W. Foden, E. Di Minin, S. Pagad, P. Genovesi, J. Hutton \& N. D. Burgess, 2016. Filling in biodiversity threat gaps. Science 352: 416418.

Kang, B., X. Huang, J. Li, M. Liu, L. Guo \& C.-C. Han, 2017. Inland Fisheries in China: Past, Present, and Future. Reviews in Fisheries Science \& Aquaculture 25: 270-285.

Kirby, J. S., A. J. Stattersfield, S. H. M. Butchart, M. I. Evans, R. F. A. Grimmett, V. R. Jones, J. O'Sullivan, G. M. Tucker \& I. Newton, 2008. Key conservation issues for migratory land- and waterbird species on the world's major flyways. Bird Conservation International 18: S49-S73.

Kristensen, T. J., 2011. Seasonal Bird Exploitation by Recent Indian and Beothuk HunterGatherers of Newfoundland. Canadian Journal of Archaeology 35: 292-322.

Lehner, B. \& P. Döll, 2004a. Development and validation of a global database of lakes, reservoirs and wetlands. Journal of Hydrology 296: 1-22.

Lehner, B. \& P. Döll, 2004b. Global Lakes and Wetlands Database GLWD. Accessed 6 June 2018.

Lévêque, C., T. Oberdorff, D. Paugy, M. L. J. Stiassny \& P. A. Tedesco, 2008. Global diversity of fish (Pisces) in freshwater. Hydrobiologia 595: 545-567.

Lymer, D., F. Marttin, G. Marmulla \& D. Bartley, 2016. A Global Estimate of Theoretical Annual Inland Capture Fisheries Harvest. In Taylor, W. W., D. M. Bartley, C. I. Goddard, N. J. Leonard \& R. Welcomme (eds) Freshwater, Fish and the Future: Proceedings of the Global Cross-Sectoral Conference. American Fisheries Society, Food and Agriculture Organization of the United Nations, Michigan State University, 63-75. 
Madsen, J., T. K. Christensen, T. J. Balsby \& I. M. Tombre, 2015. Could Have Gone Wrong: Effects of Abrupt Changes in Migratory Behaviour on Harvest in a Waterbird Population. PLoS One 10: e0135100.

Maxwell, S., R. A. Fuller, T. M. Brooks \& J. E. M. Watson, 2016. The ravages of guns, nets and bulldozers. Nature 536: 143-145.

Merkel, F. \& T. Barry (eds), 2008. Seabird harvest in the Arctic. CAFF International Secretariat, Circumpolar Seabird Group (CBird), .

Millennium Ecosystem Assessment, 2005. Ecosystems and Human Well-being. Island Press, Washington DC.

Milner-Gulland, E. J., E. L. Bennett \& SCB 2002 Annual Meeting Wild Meat Group, 2003. Wild meat: the bigger picture. Trends in Ecology \& Evolution 18: 351-357.

Mustafa, M. G. \& A. C. Brooks, 2008. Status of Fisheries Resource and Management Approach in the Open Beels of Bangladesh: A Comparative Case Study. Asian Fisheries Science

North American Waterfowl Management Plan, 2012. North American Waterfowl Management Plan: People Conserving Waterfowl and Wetlands. U.S. Department of the Interior,

Pauly, D., 2007. The Sea Around Us Project: Documenting and communicating global fisheries impacts on marine ecosystems. Ambio 36: 290-295.

Peloquin, C. \& F. Berkes, 2009. Local Knowledge, Subsistence Harvests, and Social-Ecological Complexity in James Bay. Human Ecology 37: 533-545. good, and the unknown. Annual Review of Environment and Resources 37: 25-50. 
873 Raftovich, R. V., S. C. Chandler \& K. A. Wilkins, 2016. Migratory bird hunting activity and harvest during the 2014-15 and 2015-16 hunting seasons. U.S. Fish and Wildlife Service, Laurel, Maryland.

Rahman, S., M. A. Mazid, M. Kamal, M. A. Hossain \& M. S. Hossain, 1999. Study on fishing gears, species selectivity toward gears and catch composition of BSKB beel, Khulna, Bangldesh. Bangladesh Journal of Fisheries Research 3: 25-32.

Ramsar Convention, 2000. Ramsar Sites Information Service: Tanguar Haor, Site No. 1031 https://rsis.ramsar.org/ris/1031. Ramsar Convention Bureau, Gland, Switzerland, 8. Accessed 6 June 2018.

Ramsar Convention, 2012. Resolution XI.8 Annex 2: Strategic Framework and guidelines for the future development of the List of Wetlands of International Importance of the Convention on Wetlands (Ramsar, Iran, 1971) - 2012 revision. Ramsar Convention,

Ramsar Convention on Wetlands, 2018. Global Wetland Outlook: State of the World's Wetlands and their Services to People. Ramsar Convention Secretariat, Gland, Switzerland.

Rana, M. P., M. S. H. Chowdhury, S. Sohel Msi Akhter \& M. Koike, 2009. Status and socio889 economic significance of wetland in the tropics: a study from Bangladesh. iForest Biogeosciences and Forestry 2: 172-177.

Ripple, W. J., C. Wolf, T. M. Newsome, M. G. Betts, G. Ceballos, F. Courchamp, M. W. Hayward, B. Van Valkenburgh, A. D. Wallach \& B. Worm, 2019. Are we eating the

894 Rossell, F., O. Bozsèr, P. Collen \& H. Parker, 2005. Ecological impact of beavers Castor fiber 895 and Castor canadensis and their ability to modify ecosystems. Mammal Review 35: 248896 276. 
Russi, D., P. ten Brink, A. Farmer, T. Badura, D. Coates, J. Förster, R. Kumar \& N. Davidson, 2013. The Economics of Ecosystems and Biodiversity for Water and Wetlands. IEEP \& Ramsar Secretariat, London and Brussels \& Gland.

Sandilyan, S. \& V. Duraimurugan, 2013. Extermination of birds terminates Indian agricultural prospects. International Journal of Pure and Applied Zoology 1: 48-51.

902

Sándor, C., S. Gergely, M. Mihály, K. Virág \& P. Krisztina, 2017. A vadállomány és a 903 hasznosítás fontosabb adatai számokban és diagramokban. Országos Vadgazdálkodási Adattár, Gödöllö, Hungary, 28.

Sauer, J. R., W. A. Link, J. E. Fallon, K. L. Pardieck \& D. J. Ziolkowski, 2013. The North American Breeding Bird Survey 1966-2011: Summary Analysis and Species Accounts. North American Fauna 79: 1-32.

Sayeed, M. A., 2014. Efficiency of fishing gears and their effects on fish biodiversity and 909 production in the Chalan beel. European Scientific Journal 10: 294-309.

Schlaepfer, M. A., C. Hoover \& C. K. Dodd, 2005. Challenges in evaluating the impact of the trade in amphibians and reptiles on wild populations. BioScience 55: 256-264.

912 Schuyt, K. \& L. Brander, 2004. Living Waters Conserving the source of life: The Economic Values of the World's Wetlands. WWF, Zeist, The Netherlands.

914 Siddiq, M. A., M. I. Miah, Z. F. Ahmed \& M. Asadujjaman, 2013. Present Status of Fish, Fishers and Fisheries of Dogger Beel in Hajigonj Upazila, Chandpur, Bangladesh. Journal of Aquatic Science 1: 39-45.

917 Sodhi, N. S., C. H. Sekercioglu, J. Barlow \& S. K. Robinson, 2011. Harvesting of Tropical Birds 918 Conservation of Tropical Birds. Wiley-Blackwell, 152-172.

919 Statistik Austria, 1983-2018. Bundesweite Daten zum Wildabschuss Bundesanstalt Statistik. 920 http://statcube.at/statistik.at/ext/statcube/jsf/terms.xhtml. Accessed 6 June 2018. 
921 Strayer, D. L., 2006. Challenges for freshwater invertebrate conservation. Journal of the North American Benthological Society 25: 271-287.

Truesdale, C. \& K. Brooks, 2017. A Guide to Aboriginal Harvesting Rights: Fishing, Hunting, Trapping, Gathering. Legal Services Society, Vancouver, BC.

Tsuji, L. J. S. \& E. Nieboer, 1999. A question of sustainability in Cree harvesting practices: The seasons, technological and cultural changes in the western James Bay region of northern Ontario, Canada. Canadian Journal of Native Studies XIX: 169-192.

U.S. Department of the Interior, U.S. Fish and Wildlife Service, U.S. Department of Commerce \& U.S. Census Bureau, 2016. National Survey of Fishing, Hunting, and WildlifeAssociated Recreation FHW/16-NAT(RV). U.S. Department of the Interior \& U.S. Fish \& Wildlife Service.

UN General Assembly, 2015. Transforming our world: the 2030 Agenda for Sustainable Development United Nations, New York.

UNEP \& CBD, 2010. Strategic Plan for Biodiversity 2011-2020 and the Aichi Biodiversity Targets. UNEP/CBD/COP/DEC/X/2, Nagoya, Japan.

UNEP \& CMS Secretariat, 2014. A Review of Migratory Bird Flyways and Priorities for Management CMS Technical Series No 27. UNEP / Secretariat of the Convention on the Conservation of Migratory Species of Wild Animals, Bonn, Germany, 164.

United Nations Educational Scientific and Cultural Organization (UNESCO), 1971. Convention on Wetlands of International Importance especially as Waterfowl Habitat, Ramsar (Iran).

Usher, P. J., 2002. Inuvialuit Use of the Beaufort Sea and its Resources, 1960-2000. Arctic 55: $18-28$.

Vaughn, C. C. \& C. C. Hakenkamp, 2001. The functional role of burrowing bivalves in freshwater ecosystems. Freshwater Biology 46: 1431-1446. 
945 Vences, M. \& J. Köhler, 2008. Global diversity of amphibians (Amphibia) in freshwater. Hydrobiologia 595: 569-580.

Veron, G., B. D. Patterson \& R. Reeves, 2008. Global diversity of mammals (Mammalia) in freshwater. Hydrobiologia 595: 607-617.

Wang, X., F. Kuang, K. Tan \& Z. Ma, 2018. Population trends, threats, and conservation recommendations for waterbirds in China. Avian Research 9: 14.

Wein, E. E. \& M. M. R. Freeman, 1995. Frequency of traditional food use by three Yukon First Nations living in four communities. Arctic 48: 161-171.

Welcomme, R. L., 2011. An overview of global catch statistics for inland fish. ICES Journal of Marine Science 68: 1751-1756.

Weller, M. W., 1999. Wetland birds: habitat resources and conservation implications. Cambridge University Press, Cambridge, UK.

Wetlands International, 2012. Waterbird Population Estimates, Fifth Edition. Summary Report. Wetlands International, Wageningen, The Netherlands.

Wiber, M., F. Berkes, A. Charles \& J. Kearney, 2004. Participatory research supporting community-based fishery management. Marine Policy 28: 459-468.

World Bank, 2012. Hidden Harvest: The Global Contribution of Capture Fisheries. The World Bank, Food and Agriculture Organization of the United Nations, WorldFish Center, Agriculture and Rural Development, Washington D.C.

964 WWF, 2018. Living Planet Report - 2018: Aiming Higher. WWF, Gland, Switzerland.

965 Youn, S. J., W. W. Taylor, A. J. Lynch, I. G. Cowx, T. D. Beard Jr, D. Bartley \& F. Wu, 2014. 966 Inland capture fishery contributions to global food security and threats to their future. Global Food Security 3: 142-148.

968 Ziegler, S., J. E. Fa, C. Wohlfart, B. Streit, S. Jacob \& M. Wegmann, 2016. Mapping Bushmeat Hunting Pressure in Central Africa. Biotropica 48: 405-412. 
972

973 Global offtake of wild animals from wetlands: critical issues for fish and birds

975

976

Sarah Brotherton • Chris B. Joyce • Jörn P. W. Scharlemann

977

978

979

Table S1 List of studies for fish offtake in wetlands

980

Ahmed, M. S., 2008. Assessment of fishing practices on the exploitation of the Titas floodplain in Brahmanbaria, Bangladesh. Turkish Journal of Fisheries and Aquatic Sciences 8: 329-

982 334.

983

Arlinghaus, R., T. Mehner \& I. G. Cowx, 2002. Reconciling traditional inland fisheries 984 management and sustainability in industrialized countries, with emphasis on Europe. Fish and Fisheries 3: 261-316.

Baran, E., 2005. Cambodian inland fisheries: Facts, figures and context. WorldFish Center, Penang, Malaysia.

Baran, E., N. van Zalinge \& N. P. Bun, 2001a. Analysis of the Cambodian Bagnet ("Dai") fishery data. ICLARM and Mekong River Commission Secretariat and Department of Fisheries, Penang, Malaysia and Phnom Penh, Cambodia, 50.

Baran, E., N. Van Zalinge \& N. P. Bun, 2001b. Floods, floodplains and fish production in the Mekong Basin: present and past trends. In Ahyaudin, A., M. R. Salmah, M. Mashhor, R. Nakamura, S. Ramakrishna \& T. Mundkur (eds) Proceedings of the Second Asian Malaysia, Pulau Pinang, Malaysia, 920-932. 
996 Bartley, D. M., G. J. De Graaf, J. Valbo-Jørgensen \& G. Marmulla, 2015. Inland capture 997 fisheries: status and data issues. Fisheries Management and Ecology 22: 71-77.

998 Beard, T. D., Jr., R. Arlinghaus, S. J. Cooke, P. B. McIntyre, S. De Silva, D. Bartley \& I. G. 999 Cowx, 2011. Ecosystem approach to inland fisheries: research needs and implementation $1000 \quad$ strategies. Biology Letters 7: 481-3.

1001 Béné, C. \& R. M. Friend, 2009. Water, poverty and inland fisheries: lessons from Africa and 1002 Asia. Water International 34: 47-61.

1003 Bevanger, K., A. K. Datta, A.-T. Eid \& M. Shirin, 2001. Tanguar Haor Wetland Biodiversity 1004 Conservation Project - an Appraisal NINA Project Report 16. Norwegian Institute for 1005 Nature Research (NINA), Trondheim, Norway, 1-37.

1006 Coates, D., 2001. Biodiversity and fisheries management opportunities in the Mekong River 1007 Basin. https://www.cbd.int/doc/nbsap/fisheries/Coates.pdf. Accessed 6 June 2018.

1008 Coetzee, H. C., W. Nell, E. S. Van Eeden \& E. P. De Crom, 2015. Artisanal Fisheries in the 1009 Ndumo Area of the Lower Phongolo River Floodplain, South Africa. Koedoe 57.

1010 Cooke, S. J. \& I. G. Cowx, 2004. The role of recreational fishing in global fish crises. BioScience 1011 54: $857-859$

1012 Cooke, S. J. \& K. J. Murchie, 2015. Status of aboriginal, commercial and recreational inland 1013 fisheries in North America: past, present and future. Fisheries Management and Ecology $1014 \quad 22: 1-13$.

1015 Cowx, I. G., 2015. Characterisation of inland fisheries in Europe. Fisheries Management and $1016 \quad$ Ecology 22: 78-87.

1017 Cowx, I. G., R. Arlinghaus \& S. J. Cooke, 2010. Harmonizing recreational fisheries and 1018 conservation objectives for aquatic biodiversity in inland waters. J Fish Biol 76: 2194-215.

1019 Craig, J. F., A. S. Halls, J. J. F. Barr \& C. W. Bean, 2004. The Bangladesh floodplain fisheries. $1020 \quad$ Fisheries Research 66: 271-286. 
De Graaf, G., 2003. The flood pulse and growth of floodplain fish in Bangladesh. Fisheries Management and Ecology 10: 241-247.

De Graaf, G., D. Bartley, J. Jorgensen \& G. Marmulla, 2015. The scale of inland fisheries, can we do better? Alternative approaches for assessment. Fisheries Management and Ecology 22: 64-70.

FAO, 2016. The State of World Fisheries and Aquaculture 2016. Contributing to food security and nutrition for all. Food and Agriculture Organization of the United Nations, Rome.

Funge-Smith, S. J., 2018. Review of the state of world fishery resources: inland fisheries. Food and Agriculture Organization of the United Nations, Rome.

Galib, S. M., M. A. Samad, A. B. M. Mohsin, F. A. Flowra \& M. T. Alam, 2009. Present status of fishes in the Chalan Beel the largest beel wetland of Bangladesh. International Journal

Garcez Costa Sousa, R. \& C. E. de Carvalho Freitas, 2011. Seasonal catch distribution of tambaqui (Colossoma macropomum), Characidae in a central Amazon floodplain lake:

Halls, A. S., D. D. Hoggarth \& K. Debnath, 1999. Impacts of hydraulic engineering on the dynamics and production potential of floodplain fish populations in Bangladesh. Fisheries Management and Ecology 6: 261-285.

Hortle, K. G. \& P. Bamrungrach, 2015. Fisheries Habitat and Yield in the Lower Mekong Basin. MRC Technical Paper No 47. Phnom Penh, Cambodia, 80.

Hossain, M. S., M. S. Islam, P. Mondal \& M. E. Hoq, 2011-12. Assessment of aquatic natural resources in the Tanguar haor at Sunamgonj, Bangladesh. Bangladesh Journal of Fisheries Research 15-16: 81-92. 
Indian Agricultural Statistics Research Institute, 2011. Manual on Fishery Statistics. Government of India, Ministry of Statistics and Programme Implementation, Central Statistics Office, New Delhi.

Kang, B., X. Huang, J. Li, M. Liu, L. Guo \& C.-C. Han, 2017. Inland Fisheries in China: Past, Present, and Future. Reviews in Fisheries Science \& Aquaculture 25: 270-285.

Lymer, D., F. Marttin, G. Marmulla \& D. Bartley, 2016. A Global Estimate of Theoretical Annual Inland Capture Fisheries Harvest. In Taylor, W. W., D. M. Bartley, C. I. Goddard, N. J. Leonard \& R. Welcomme (eds) Freshwater, Fish and the Future: Proceedings of the Global Cross-Sectoral Conference. American Fisheries Society, Food and Agriculture Organization of the United Nations, Michigan State University, 63-75.

Ottaviani, D., C. De Young \& S. Tsuji, 2016. Assessing water availability and economic, social and nutritional contributions from inland capture fisheries and aquaculture : An indicatorbased framework FAO Fisheries and Aquaculture Technical Paper No 602. Food and Agriculture Organization of the United Nations, Rome, Italy, 118.

Peirson, G., D. Tingley, J. Spurgeon \& A. Radford, 2001. Economic evaluation of inland fisheries in England and Wales. Fisheries Management and Ecology 8: 415-424.

Post, J. R., M. Sullivan, S. Cox, N. P. Lester, C. J. Walters, E. A. Parkinson, A. J. Paul, L. Jackson \& B. J. Shuter, 2002. Canada's recreational fisheries: The invisible collapse? Fisheries 27: $6-17$.

Ramsar Convention, 2000. Ramsar Sites Information Service: Tanguar Haor, Site No. 1031 https://rsis.ramsar.org/ris/1031. Ramsar Convention Bureau, Gland, Switzerland, 8.

Rana, M. P., M. S. H. Chowdhury, S. Sohel Msi Akhter \& M. Koike, 2009. Status and socioeconomic significance of wetland in the tropics: a study from Bangladesh. iForest Biogeosciences and Forestry 2: 172-177. 
Thein, H., 2015. Inland fisheries resource enhancement and conservation practices in Myanmar. In Romana-Eguia, M. R. R., F. D. Parado-Estepa, N. D. Salayo \& M. J. H. Lebata-Ramos (eds) Resource Enhancement and Sustainable Aquaculture Practices in Southeast Asia: Challenges in Responsible Production of Aquatic Species: Proceedings of the International Workshop on Resource Enhancement and Sustainable Aquaculture Practices in Southeast Asia 2014 (RESA). Aquaculture Dept., Southeast Asian Fisheries Development Center, Tigbauan, Iloilo, Philippines, 67-75.

Welcomme, R. L., 2001. Inland fisheries: ecology and management. Food and Agriculture Organization of the United Nations and Blackwell Science, Oxford.

Welcomme, R. L., 2011a. FAO review of the state of the world fishery resources: Inland fisheries FAO Fisheries and Aquaculture Circular No 942. Food and Agriculture Organization of the United Nations, Rome, Italy, 97.

Welcomme, R. L., 2011b. An overview of global catch statistics for inland fish. ICES Journal of Marine Science 68: 1751-1756.

Welcomme, R. L., I. G. Cowx, D. Coates, C. Bene, S. Funge-Smith, A. Halls \& K. Lorenzen, 2010. Inland capture fisheries. Philosophical Transactions of the Royal Society B: Biological Sciences 365: 2881-96.

Welcomme, R. L., J. Valbo-Jorgensen \& A. S. Halls, 2014. Inland fisheries evolution and management - case studies from four continents FAO Fisheries and Aquaculture Technical Paper No 579. Food and Agriculture Organization of the United Nations, Rome, Italy.

Welcomme, R., 2008. World prospects for floodplain fisheries. Ecohydrology \& Hydrobiology 8: $169-182$.

World Bank, 2012. Hidden Harvest: The Global Contribution of Capture Fisheries. The World Bank, Food and Agriculture Organization of the United Nations, WorldFish Center, Agriculture and Rural Development, Washington D.C. 
Table S2 List of studies for waterbird offtake in wetlands

Aaltola, E. \& M. Oksanen, 2002. Species conservation and minority rights: The case of springtime bird hunting in Åland. Environmental Values 11: 443-460.

Andreotti, A., V. Guberti, R. Nardelli, S. Pirrello, L. Serra, S. Volponi \& R. E. Green, 2018. Economic assessment of wild bird mortality induced by the use of lead gunshot in European wetlands. Science of the Total Environment 610-611: 1505-1513.

Barbosa, A., 2001. Hunting impact on waders in Spain: effects of species protection measures. Biodiversity and Conservation 10: 1703-1709.

BirdLife International, 2017. Review of illegal killing and taking of birds in Northern and Central Europe and the Caucasus. BirdLife International, Cambridge, UK, 74.

Boere, G. C. \& T. Piersma, 2012. Flyway protection and the predicament of our migrant birds: A critical look at international conservation policies and the Dutch Wadden Sea. Ocean \& Coastal Management 68: 157-168.

Brochet, A.-L., W. Van Den Bossche, S. Jbour, P. K. Ndang’Ang’A, V. R. Jones, W. A. L. I. Abdou, A. R. Al- Hmoud, N. G. Asswad, J. C. Atienza, I. Atrash, N. Barbara, K. Bensusan, T. Bino, C. Celada, S. I. Cherkaoui, J. Costa, B. Deceuninck, K. S. Etayeb, C. FeltrupAzafzaf, J. Figelj, M. Gustin, P. Kmecl, V. Kocevski, M. Korbeti, D. Kotrosan, J. Mula Laguna, M. Lattuada, D. Leitao, P. Lopes, N. Lopez-Jimenez, V. Lucic, T. Micol, A. Moali, Y. Perlman, N. Piludu, D. Portolou, K. Putilin, G. Quaintenne, G. Ramadan-Jaradi, M. Ruzic, A. Sandor, N. Sarajli, D. Saveljic, R. D. Sheldon, T. Shialis, N. Tsiopelas, F. Vargas, C. Thompson, A. Brunner, R. Grimmett \& S. H. M. Butchart, 2016. Preliminary assessment of the scope and scale of illegal killing and taking of birds in the Mediterranean. Bird Conservation International 26: 1-28. 
1118 Brochet, A.-L., W. Van Den Bossche, V. R. Jones, H. Arnardottir, D. Damoc, M. Demko, G.

1119 Driessens, K. Flensted, M. Gerber, M. Ghasabyan, D. Gradinarov, J. Hansen, M. Horvath, 1120 M. Karlonas, J. Krogulec, T. Kuzmenko, L. Lachman, T. Lehtiniemi, P. Lorge, U. Lötberg, 1121 J. Lusby, G. Ottens, J.-Y. Paquet, A. Rukhaia, M. Schmidt, P. Shimmings, A. Stipnieks, E. 1122 Sultanov, Z. Vermouzek, A. Vintchevski, V. Volke, G. Willi \& S. H. M. Butchart, 2019. 1123 Illegal killing and taking of birds in Europe outside the Mediterranean: assessing the scope 1124 and scale of a complex issue. Bird Conservation International 29: 10-40.

1125 CAFF, 2014. Arctic Migratory Birds Initiative (AMBI): Protecting Arctic lifestyles and peoples 1126 through migratory bird conservation, Expert Workshop Report, Montreal, Canada, 1127 February 2014. CAFF Strategies Series No 5. Conservation of Arctic Flora and Fauna, $1128 \quad$ Akureyri, Iceland.

1129 Christensen, T. K., J. Madsen, T. Asferg, J. P. Hounisen \& L. Haugaard, 2017. Assessing hunters' 1130 ability to identify shot geese: implications for hunting bag accuracy. European Journal of $1131 \quad$ Wildlife Research 63: 20.

1132 Clausen, K. K., T. K. Christensen, O. M. Gundersen, J. Madsen \& D. Thompson, 2017. Impact 1133 of hunting along the migration corridor of pink-footed geese Anser brachyrhynchus 1134 implications for sustainable harvest management. Journal of Applied Ecology 54: 1563$1135 \quad 1570$.

1136 Convention on Migratory Species, 2005. Country report for Central Asian flyway overview: 1137 Bangladesh. CMS/CAF/Inf.4.8. Ministry of Environment and Forests, Government of the $1138 \quad$ Peoples' Republic of Bangladesh.

1139 Elmberg, J., P. Nummi, H. Pöysä, K. Sjöberg, G. Gunnarsson, P. Clausen, M. Guillemain, D. 1140 Rodrigues \& V.-M. Väänänen, 2006. The scientific basis for new and sustainable 1141 management of migratory European ducks. Wildlife Biology 12: 121-127. 
1142 Fernandes-Ferreira, H., S. V. Mendonça, C. Albano, F. S. Ferreira \& R. R. N. Alves, 2011.

1143 Hunting, use and conservation of birds in Northeast Brazil. Biodiversity and Conservation $1144 \quad 21: 221-244$.

1145 Fox, A. D., B. S. Ebbinge, C. Mitchell, T. Heinicke, T. Aarvak, K. Colhoun, P. Clausen, S. 1146 Dereliev, S. Faragó \& K. Koffijberg, 2010. Current estimates of goose population sizes in 1147 western Europe, a gap analysis and assessment of trends. Ornis Svecica 20: 115-127.

1148 Fox, A. D., J. E. Jónsson, T. Aarvak, T. Bregnballe, T. K. Christensen, K. K. Clausen, P. Clausen,

1149 L. Dalby, T. E. Holm \& D. Pavón-Jordan, Current and potential threats to Nordic duck $1150 \quad$ populations - a horizon scanning exercise. In: Annales Zoologici Fennici, 2015. vol 52. $1151 \quad$ BioOne, p 193-221.

1152 Gilliland, S. G., H. Grant Gilchrist, R. F. Rockwell, G. J. Robertson, J.-P. L. Savard, F. Merkel 1153 \& A. Mosbech, 2009. Evaluating the sustainability of harvest among Northern Common 1154 Eiders Somateria mollissima borealis in Greenland and Canada. Wildlife Biology 15: 24115536.

1156 Gray, B. T. \& R. M. Kaminski, 1994. Illegal Waterfowl Hunting in the Mississippi Flyway and 1157 Recommendations for Alleviation. Wildlife Monographs 127: 3-60.

1158 Guillemain, M., P. Aubry, B. Folliot \& A. Caizergues, 2016. Duck hunting bag estimates for the 2013/14 season in France. Wildfowl 66: 126-141.

1160 Hirschfeld, A. \& A. Heyd, 2005. Mortality of migratory birds caused by hunting in Europe: bag 1161 statistics and proposals for the conservation of birds and animal welfare. Berichte zum $1162 \quad$ Vogelschutz 42: 47-74.

1163 Ilyashenko, E. \& C. Mirande, In prep. Illegal take including hunting, trapping, and poisoning, in 1164 Crane Conservation Strategy. In Mirande, C. \& J. Harris (eds) Crane Conservation 1165 Strategy. vol UNEP/CMS/PPWG2/Doc.5. International Crane Foundation, Baraboo, 1166 Wisconsin, USA. 
1167 Johnson, F. A., M. Alhainen, A. D. Fox, J. Madsen \& M. Guillemain, 2018. Making do with less: 1168 must sparse data preclude informed harvest strategies for European waterbirds? Ecological $1169 \quad$ Applications 28: 427-441.

1170 Kamennova, I., A. Solokha, M. v. Leeuwen, F. Hoffmann \& N. Racz (eds), 2015. Strategy for 1171 the conservation of migratory waterbirds in Arctic wetlands: Nenets Autonomous Okrug, 1172 Russian Federation, 2015-2025. Wetlands Internantional, Wageningen.

1173 Kirby, J. S., A. J. Stattersfield, S. H. M. Butchart, M. I. Evans, R. F. A. Grimmett, V. R. Jones, J. O'Sullivan, G. M. Tucker \& I. Newton, 2008. Key conservation issues for migratory land- and waterbird species on the world's major flyways. Bird Conservation International

Madsen, J., K. K. Clausen, T. K. Christensen \& F. A. Johnson, 2016. Regulation of the hunting season as a tool for adaptive harvest management — first results for pink-footed geeseAnser brachyrhynchus. Wildlife Biology 22: 204-208.

Madsen, J., M. Guillemain, S. Nagy, P. Defos du Rau, J.-Y. Mondain-Monval, C. Griffin, J. H. Williams, N. Bunnefeld, A. Czajkowski, R. Hearn, A. Grauer, M. Alhainen \& A. Middleton, 2015c. Towards sustainable management of huntable migratory waterbirds in Europe: A report by the Waterbird Harvest Specialist Group of Wetlands International.

Madsen, J., N. Bunnefeld, S. Nagy, C. Griffin, P. Defos du Rau, J. Y. Mondain-Monval, R. Hearn, A. Czajkowski, A. Grauer, F. R. Merkel, J. H. Williams, M. Alhainen, M. Guillemain, A. Middleton, T. K. Christensen \& O. Noe, 2015a. Guidelines on Sustainable Harvest of Migratory Waterbirds. AEWA Conservation Guidelines No. 5 AEWA Technical Series No 62. Agreement on the Conservation of African-Eurasian Migratory Waterbirds (AEWA), Bonn, Germany. 
1191 Madsen, J., T. K. Christensen, T. J. Balsby \& I. M. Tombre, 2015b. Could Have Gone Wrong:

1192 Effects of Abrupt Changes in Migratory Behaviour on Harvest in a Waterbird Population.

$1193 \quad$ PLoS One 10: e0135100.

1194 Mooij, J., 2005. Protection and use of waterbirds in the European Union. Beiträge zur Jagd-und $1195 \quad$ Wildforschung 30: 49-76.

1196 Naves, L. C. \& J. A. Fall, 2017. Calculating food production in the subsistence harvest of birds 1197 and eggs. Arctic 70: 86-100.

1198 Otis, D. L., 2004. Mallard harvest distributions in the Atlantic and Mississippi flyways during 1199 periods of restrictive and liberal hunting regulations. Journal of Wildlife Management 68: $1200 \quad 351-359$.

1201 Quan, R. C., X. Wen \& X. Yang, 2002. Effects of human activities on migratory waterbirds at Lashihai Lake, China. Biological Conservation 108: 273-279.

Ramachandran, R., A. Kumar, K. S. Gopi Sundar \& R. S. Bhalla, 2017. Hunting or habitat? Drivers of waterbird abundance and community structure in agricultural wetlands of southern India. Ambio 46: 613-620.

Sandilyan, S. \& V. Duraimurugan, 2013. Extermination of birds terminates Indian agricultural prospects. International Journal of Pure and Applied Zoology 1: 48-51.

Schneider-Jacoby, M. \& A. Spangenberg, 2010. Bird hunting along Adriatic Flyway-an assessment of bird hunting in Albania, Bosnia and Herzegovina, Croatia, Montenegro, Slovenia and Serbia. In Denac, D., M. Schneider-Jacoby \& B. Stumberger (eds) Adriatic

1212 Sodhi, N. S., C. H. Sekercioglu, J. Barlow \& S. K. Robinson, 2011. Harvesting of Tropical Birds Conservation of Tropical Birds. Wiley-Blackwell, 152-172. 
1214 UNEP \& CMS Secretariat, 2014. A Review of Migratory Bird Flyways and Priorities for 1215 Management CMS Technical Series No 27. UNEP / Secretariat of the Convention on the 1216 Conservation of Migratory Species of Wild Animals, Bonn, Germany, 164.

1217 United Nations Environment Programme (UNEP) \& Secretariat of the Convention on the 1218 Conservation of Migratory Species of Wild Animals (CMS), 2012. A bird's eye view on 1219 flyways: A brief tour by the Convention on the Conservation of Migratory species of Wild Animals. UNEP / CMs secretariat, Bonn, Germany, 64.

1221 Wang, X., F. Kuang, K. Tan \& Z. Ma, 2018. Population trends, threats, and conservation recommendations for waterbirds in China. Avian Research 9: 14.

Watts, B. D. \& C. Turrin, 2016. Assessing hunting policies for migratory shorebirds throughout the Western Hemisphere. Wader Study 123.

1225 Williams, B. K. \& F. A. Johnson, 1995. Adaptive Management and the Regulation of Waterfowl Harvests. Wildlife Society Bulletin 23: 430-436.

1227 Williams, J. H., T. J. S. Balsby, H. Orsted Nielsen, T. Asferg \& J. Madsen, 2019. Managing geese with recreational hunters? Ambio 48: 217-229.

1229 


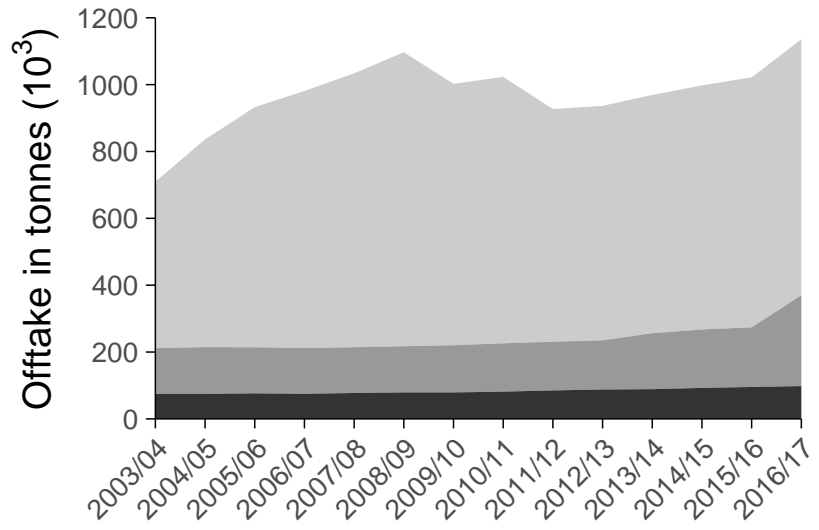




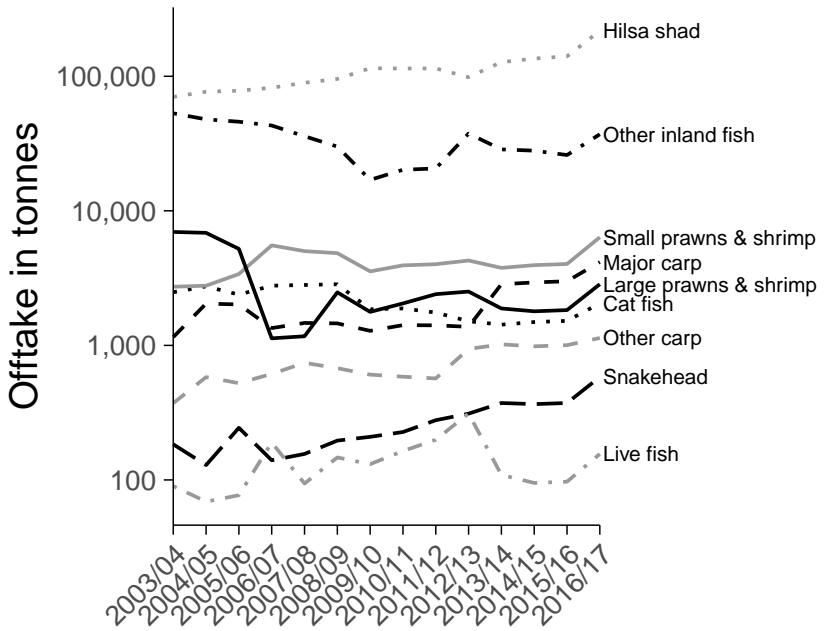




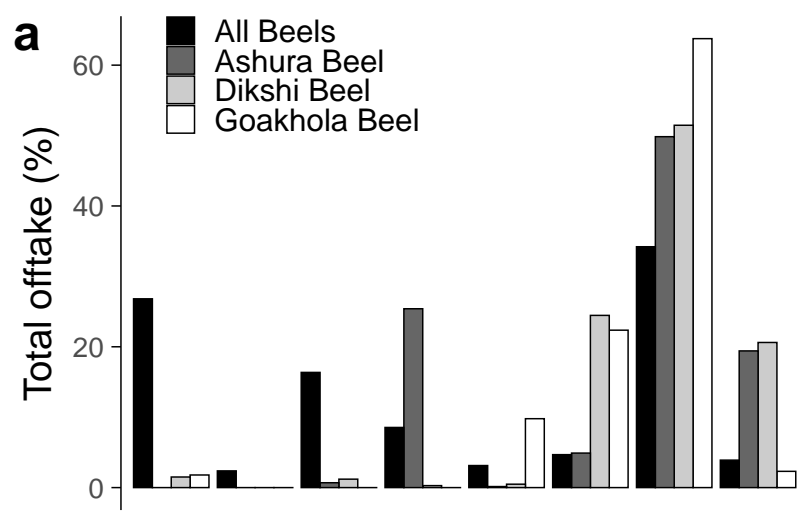

\section{b $50-\quad$ Category by species}

ऽ $40-\square$ DOF categories
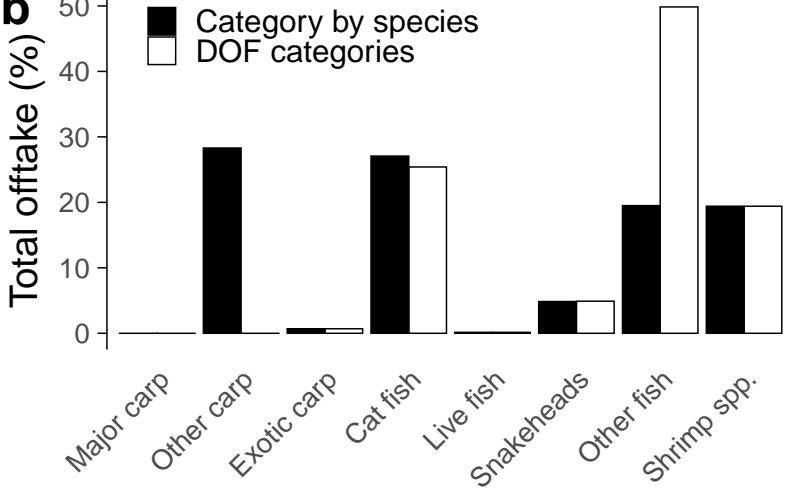
a $2000-$ Canada
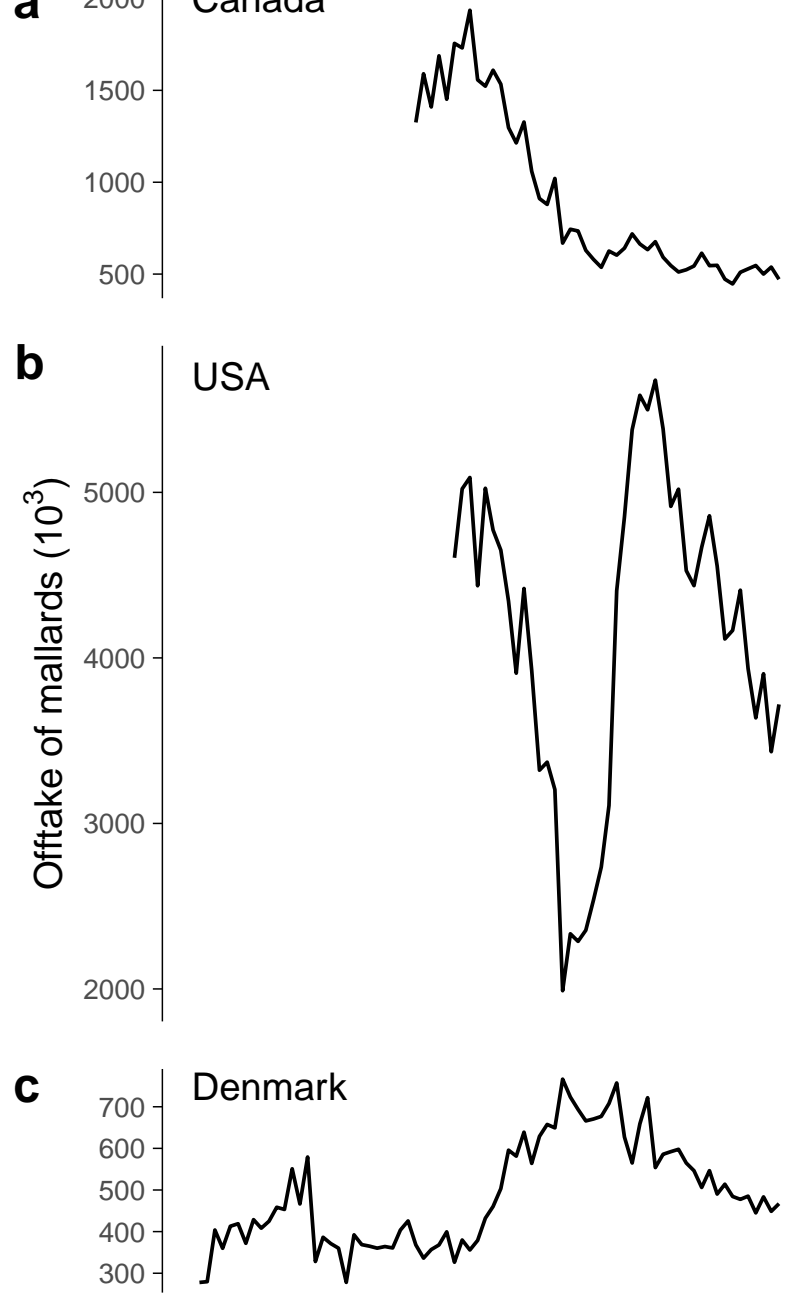

d $\begin{array}{r}10-\text { Switzerland } \\ 8 \\ 6\end{array}$
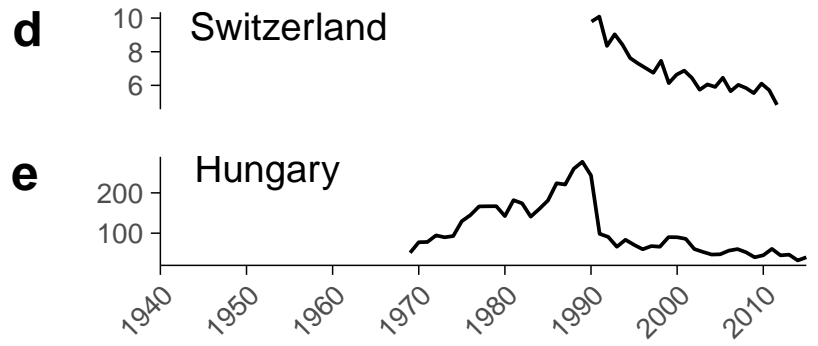


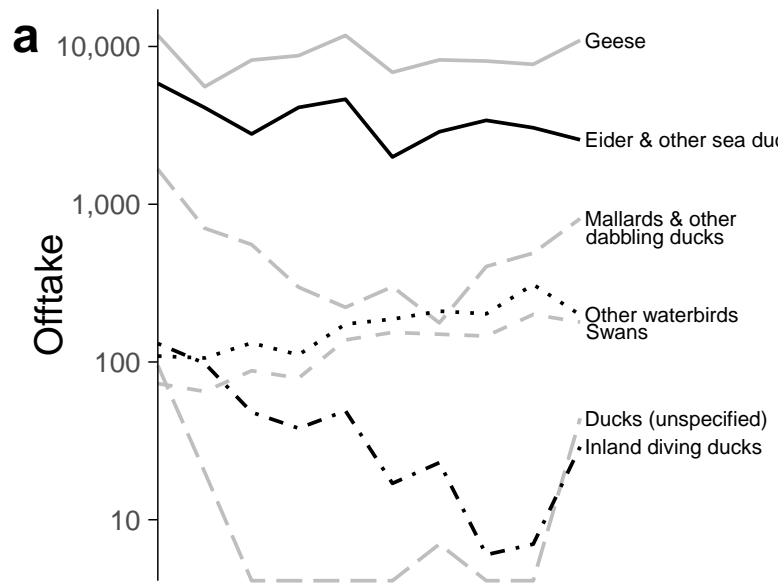

b

b

$3,000-1$

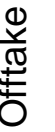
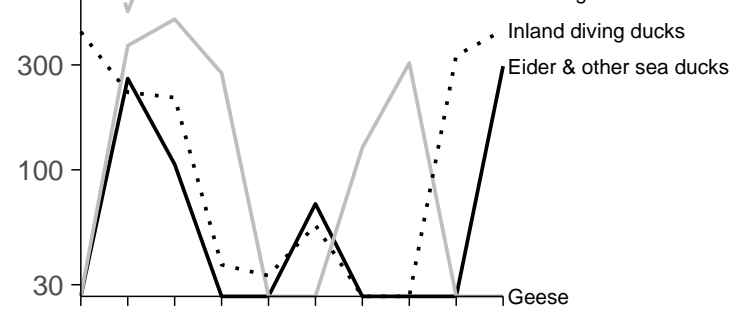

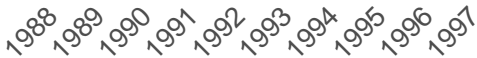

